\title{
THE SPATIAL BIAS OF FEDERAL HOUSING \\ LAW AND POLICY: CONCENTRATED POVERTY IN URBAN AMERICA
}

\section{MICHAEL H. SCHILL† AND SUSAN M. WACHTER ††}

Problems associated with poverty are not new to American cities. Nevertheless, in recent years a consensus has developed that increasing concentrations of very poor, predominantly minority households in inner-city communities have generated especially severe social pathologies ranging from persistent unemployment and welfare dependency to crime and drug abuse. Patterns of geographically concentrated inner-city poverty are rooted in a number of demographic and social dynamics including urban deindustrialization, the breakdown of the nuclear family, race discrimination, and the adverse impacts of government policies. In this Article, we examine one surprisingly important and underexamined cause of concentrated inner-city poverty-federal housing law and policy. Throughout the twentieth century, federal housing law and policy have exhibited a locational bias that has promoted the growth of large concentrations of poor people in the inner city.

In Part I, we briefly describe the increase in concentrated poverty that has taken place in American cities over the past two decades as well as the problems it generates. In Part II, we examine how federal housing policies of the past sixty years have contributed to concentrated inner-city poverty. Particular emphasis is placed upon the federal Public Housing Program. In addition to describing how public housing promoted concentrated poverty within its walls, we examine whether the program negatively affected urban neighborhoods. We use data from the city of Philadelphia to test whether the location of public housing in a neighborhood affects overall poverty rates within that community. Our findings suggest that the existence of public housing in a neighborhood contributes

† Professor of Law and Real Estate, University of Pennsylvania Law School and the Wharton School of the University of Pennsylvania, and Director, New York University School of Law Center for Real Estate and Urban Policy.

t† Associate Professor of Finance and Real Estate, the Wharton School of the University of Pennsylvania. We would like to thank William Carter, Scott Kieff, and Woohyung Yang for their assistance with our research. We also gratefully acknowledge the receipt of financial support for this research from the Mortgage Bankers Association of America, the Wharton Real Estate Center, and the Institute for Law and Economics of the University of Pennsylvania Law School. 
substantially to concentrated inner-city poverty. Part II also shows how federal mortgage assistance programs may have destabilized inner-city neighborhoods by redlining areas with significant proportions of minority households. Efforts by the federal government in the late 1960 s to remedy the negative effects of these programs paradoxically led to increased levels of abandonment and deterioration in many of these same neighborhoods.

The locational biases of federal housing policy are not merely matters of history. Part III describes how current housing programs and laws continue to foster the isolation of low-income families in inner-city communities. In particular, we use data from the Boston metropolitan area to examine how the Community Reinvestment Act, a law designed to increase access to home ownership in lowincome neighborhoods, may actually reinforce concentrated poverty in American cities. We conclude in Part IV by describing changes in federal housing subsidy programs and law enforcement that might promote the objective of deconcentrating the inner-city poor.

\section{The Growth of Concentrated INNER-City Poverty}

Since the mid-1980s, social scientists have conducted extensive research on the geography of poverty in American cities. Typically, these studies use census tracts as convenient proxies for neighborhoods and characterize particular threshold levels of households earning incomes below the poverty level as "extreme poverty" or "underclass" areas. For example, Paul Jargowsky and Mary Jo Bane report that from 1970 to 1980 , the number of poor people living in tracts with $40 \%$ or more of their populations composed of poor people increased by $29.5 \%$ to $2,449,324{ }^{1}$

Despite the economic boom of the 1980s, data from the 1990 Census of Population and Housing demonstrate that concentrated inner-city poverty continued to grow over the past decade. In a recent article, Kasarda presents census data for several different neighborhood classification types. Among these neighborhoods are "extreme poverty" tracts in which $40 \%$ of the residents are impoverished and "distressed" neighborhoods in which the proportion of

${ }^{1}$ See Paul A. Jargowsky \& Mary Jo Bane, Ghetto Poverty in the United States, 1970 1980, in THE URBAN UNDERCLASS 235, 252 (Christopher Jencks \& Paul E. Peterson eds., 1991); see also Richard P. Nathan \& Charles F. Adams, Jr., Four Perspectives on Urban Hardship, 104 POL. SCI. Q. 483, 503 (1989); John C. Weicher, How Poverly Neighborhoods Are Changing, in INNER-CITY POVERTY IN THE UNITED STATES 68, 70 (Laurence E. Lynn, Jr. \& Michael G.H. McGeary eds., 1990). 
residents who are simultaneously below the poverty line, unemployed, living in female-headed households and receiving public assistance falls at least one or more standard deviations above the average for all tracts in $1980 .^{2}$

As Tables I and II demonstrate, the number of people living in each of these two types of neighborhoods rose between 1980 and 1990. For extreme poverty tracts, the population actually increased at a faster rate during the 1980s than it had during the 1970s. These data also indicate that concentrated poverty increased its spatial reach over the period from 1980 to 1990, affecting a growing number of census tracts.

\section{TABLE I}

EXTREME POVERTY TRACTS FOR LARGEST 100 CITIES (1970-1990) ${ }^{3}$

(Unless otherwise specified, numbers are percentages.)

\begin{tabular}{|c|c|c|c|}
\hline CHARACTERISTIC & 1970 & 1980 & 1990 \\
\hline Number of Tracts & 751 & 1331 & 1954 \\
\hline $\begin{array}{l}\text { Tracts as Percentage of All Tracts } \\
\text { in Cities }\end{array}$ & 6.0 & 9.7 & 13.7 \\
\hline Population (in 1000s) & 2691 & 3833 & 5496 \\
\hline $\begin{array}{l}\text { Population as Percentage of } \\
\text { Cities' Population }\end{array}$ & 5.2 & 7.9 & 10.7 \\
\hline $\begin{array}{l}\text { Proportion of Population Non- } \\
\text { Hispanic White }\end{array}$ & 18.6 & 14.6 & 15.5 \\
\hline $\begin{array}{l}\text { Proportion of Population Non- } \\
\text { Hispanic Black }\end{array}$ & 64.8 & 64.4 & 57.3 \\
\hline Proportion of Population Hispanic & 15.2 & 19.3 & 23.8 \\
\hline $\begin{array}{l}\text { Proportion of Persons Aged 16-19 Who Are } \\
\text { High School Dropouts }\end{array}$ & 24.2 & 21.9 & 19.4 \\
\hline $\begin{array}{l}\text { Proportion of Households Receiving } \\
\text { Public Assistance }\end{array}$ & 28.1 & 36.4 & 32.8 \\
\hline $\begin{array}{l}\text { Proportion of Men Not Working During } \\
\text { Previous Year }\end{array}$ & 30.9 & 42.8 & 40.4 \\
\hline
\end{tabular}

2 John D. Kasarda, Inner-City Concentrated Poverty and Neighborhood Distress: 1970 to 1990, 4 Housing POL'y DEBATE 253, 256 (1993).

${ }^{3}$ See id. at 258, 263, 271-75. 


\section{TABLE II}

Distressed TRACTS FOR LARGEST 100 CITIES (1970-1990) ${ }^{4}$

(Unless otherwise specified, numbers are percentages.)

\begin{tabular}{||l|c|c|c|}
\hline \multicolumn{1}{|c|}{ CHARACTERISTIC } & 1970 & 1980 & 1990 \\
\hline \hline Number of Tracts & 296 & 1513 & 1850 \\
\hline $\begin{array}{l}\text { Tracts as Percentage of All Tracts } \\
\text { in Cities }\end{array}$ & 2.4 & 11.0 & 13.0 \\
\hline Population (in 1000s) & 1022 & 4893 & 5704 \\
\hline $\begin{array}{l}\text { Population as Percentage of } \\
\text { Cities' Population }\end{array}$ & 1.7 & 10.0 & 11.1 \\
\hline $\begin{array}{l}\text { Proportion of Population Non-Hispanic } \\
\text { White }\end{array}$ & 14.8 & 10.1 & 10.4 \\
\hline $\begin{array}{l}\text { Proportion of Population Non-Hispanic } \\
\text { Black }\end{array}$ & 76.6 & 72.4 & 67.7 \\
\hline Proportion of Population Hispanic & 7.1 & 16.2 & 19.6 \\
\hline $\begin{array}{l}\text { Proportion of Persons Aged 16-19 Who } \\
\text { Are High School Dropouts }\end{array}$ & 26.7 & 23.1 & 21.4 \\
\hline $\begin{array}{l}\text { Proportion of Households Receiving } \\
\text { Public Assistance }\end{array}$ & 36.2 & 36.4 & 34.6 \\
\hline
\end{tabular}

Important regional differences exist in the growth rates of concentrated inner-city poverty between 1980 and 1990. Both the population living in these neighborhoods as well as the aggregate number of neighborhoods rose in the Midwest and the South, but decreased in the Northeast. ${ }^{5}$ Cities with the largest increase in populations living in extreme poverty tracts were Detroit, Los Angeles, Houston, Milwaukee, and Fresno. ${ }^{6}$ Cities that experienced the greatest declines in the number of residents in these neighborhoods were Newark, New York, Philadelphia, Baltimore, and

${ }^{4}$ See id. at $258,263,274-75$.

${ }^{5}$ See id. at 258-62. The number of extreme poverty tracts and distressed neighborhoods slightly increased in the West from 1980 to 1990 , but the number of severely distressed tracts fell. See id. at 262. Note, however, that the numbers of poverty, extreme poverty, distressed, and severely distressed tracts grew in all four regions between 1970 and 1980 . See id. at 259-60.

${ }^{6}$ See id. at 295. 
Jacksonville. ${ }^{7}$ In both extreme poverty and distressed tracts, the overwhelming majority of residents in 1990 were racial minorities. ${ }^{8}$ Nevertheless, from 1980 to 1990, the proportion composed of Hispanics and non-Hispanic whites increased slightly. ${ }^{9}$

Concentrated inner-city poverty generates problems that are different both in kind and in magnitude from those experienced by poor people in other geographic settings. William Julius Wilson, in his 1987 book The Truly Disadvantaged, ${ }^{10}$ argues that the geographic isolation of poor people generates behavioral adaptations called "concentration effects." neighborhoods with few employed role models develop weak attachments to the labor force. ${ }^{12}$ Lacking employment opportunities and the appropriate socialization to seek work, youths frequently engage in deviant or illegal activities to earn income and gain status, thereby further distancing themselves from middle-class norms. ${ }^{13}$ These behaviors are reinforced by peer groups. Activities that are likely to assist them in obtaining employment and social mobility, such as graduating from high school, are stigmatized rather than valued. ${ }^{14}$

\footnotetext{
${ }^{7}$ See id. at 299.
}

${ }^{8}$ In $\mathbf{1 9 9 0 ,}$,blacks made up $\mathbf{5 7 . 3}$ percent of the population in extreme poverty tracts, Hispanics made up 23.8 percent, and non-Hispanic Whites 15.5 percent." Id. at 264.

${ }^{9}$ See id. at 264-65 ("[N]on-Hispanic whites marginally increased their proportions between 1980 and 1990 in both extreme poverty and distressed tracts . . . . The proportions of blacks declined, largely because of substantial increases in the absolute number of Hispanics in extreme poverty and distressed tracts.").

${ }^{10}$ William J. Wilson, The TRULy Disadvantaged: THE INNER City, the UNDERCLASS, AND PUBLIC POLICY (1987).

"Id. at 58 (stating that the term "concentration effects" "capture[s] the differences in the experiences of low-income families who live in inner-city areas from ... those who live in other areas in the central city today").

${ }^{12}$ See id. at 56-57 (explaining that when poor youths live in economically diverse communities, a "social buffer" exists because by observing education, steady employment, and family stability, they grow to understand that there are social norms).

${ }^{13}$ See id. at 57-58; see also William J. Wilson, Studying Inner-City Social Dislocations: The Challenge of Public Agenda Research, 56 AM. Soc. REv. 1, 12 (1991) ("The issue is not simply that the underclass or ghetto poor have a marginal position in the labor market. . . . it is also that their economic position is uniquely reinforced by their social milieu.").

${ }_{14}$ Douglas Massey and Nancy Denton suggest that youths living in concentrated poverty neighborhoods adopt "oppositional cultures" to protect their self esteem and engender the respect of peers. Among the elements of this culture most harmful to their future employment prospects is the devaluation of academic success as "acting white." See Douglas S. MASSEY \& NANCY A. DENTON, AMERICAN APARTHEID: SEGREGATION AND THE MAKING OF THE UNDERCLASS 167-76 (1993). 
Wilson's concentration effects hypothesis has received almost universal empirical confirmation. Although the precise causal mechanism remains a matter of debate, studies testing the theory demonstrate a consistent relationship between social and spatial isolation on the one hand, and high rates of teenage childbearing, school dropouts, and welfare dependency on the other. ${ }^{15}$

\section{The Interplay Between Past Federal Housing Policies AND THE GROWTH OF CONCENTRATED INNER-GITY POVERTY}

Federal housing policy has historically played an important, albeit nonexclusive, ${ }^{16}$ role in the creation of urban ghettos. This locational bias is exhibited in interventions to assist both renters and home owners. In this Part, we examine how the public housing program and homeowner mortgage assistance programs have contributed to the concentration of poverty in the inner city.

${ }^{15}$ See REBECCA L. CLARK, NEIGHBORHOOD EFFECTS ON DROPPING OUT OF SCHOOL Among TEENAGE Boys 16-21 (Urban Inst. Discussion Paper No. PSC-DSC-UI-13, 1992) (reporting that the rate of school dropouts among boys increases both as the proportion of poor households in a community increases and as the proportion of households employed in middle-class occupations declines, although the results do not support a contagion theory); Elijah Anderson, Neighborhood Effects on Teenage Pregnancy, in THE URBAN UNDERCLASS, supra note 1, at 375, 382-97 (describing cultural explanations for teenage pregnancy in ghetto communities); Jeanne BrooksGunn et al., Do Neighborhoods Influence Child and Adolescent Development?, 99 AM. J. Soc. 353, 384-85 (1993) (concluding that the presence of affluent neighbors decreases the likelihood that teenagers will have children and drop out of school); Jonathan Crane, The Epidemic Theory of Ghettos and Neighborhood Effects on Dropping out and Teenage Childbearing, 96 AM. J. Soc. 1226, 1236 (1991) (demonstrating that as the proportion of high-status jobholders in a community declines, the rate of school dropouts increases exponentially, thereby supporting the contagion model); Paul Osterman, Welfare Participation in a Full Employment Economy: The Impact of Neighborhood, 38 Soc. PROB. 475, 486-88 (1991) (stating that as the proportion of employed persons in a community decreases, the likelihood that an individual resident will receive public assistance increases).

${ }^{16}$ For discussions of other forces that have contributed to create or exacerbate concentrated inner-city poverty, see generally MYRON MAGNET, THE DREAM AND THE NIGHTMARE: THE SIXTIES' LEGACY TO THE UNDERCLASS (1993) (describing liberal cultural norms of the 1960s); MASSEY \& DENTON, supra note 14 (discussing economic restructuring and race discrimination); LAWRENCE M. MEAD, THE NEW POLITICS OF POVERTY: THE NONWORKING POOR IN AMERICA (1992) (delineating the characterological flaws among poor people); CHARLES MURRAY, LOSING GROUUND (1984) (exploring the role of social welfare programs in exacerbating the problem of inner-city poverty); WILSON, supra note 10 (observing economic restructuring and out-migration of the black middle class). 


\section{A. The Public Housing Program}

The federal housing program that has generated the most intense pattern of concentrated poverty is the public housing program. The modern public housing program traces its roots to the mid-1930s, when the Public Works Administration purchased land and built publicly owned housing. ${ }^{17}$ In 1935, however, a federal court struck down this program in United States v. Certain Lands in Louisville. ${ }^{18}$ The court reasoned that providing housing to low-salaried workers and residents of slum districts was not a public purpose and therefore was beyond the scope of the government's eminent domain powers. ${ }^{19}$

The Louisville case had enormously important implications for the structure of the public housing program that emerged in the Housing Act of $1937 .{ }^{20}$ Instead of being owned by the federal government, public housing would be owned and operated by local public housing authorities (PHAs) created by states and localities. ${ }^{21}$ Municipalities that wished to participate in the program would establish a PHA and enter into an Annual Contribution Contract (ACC) with the federal government. ${ }^{22}$ Under the ACC, the federal government funded the majority of the capital costs of public housing by paying the debt service on long-term bonds. ${ }^{23}$ The PHA, in turn, agreed to operate the housing over the life of the bonds, subject to federal statutes and regulations.

${ }^{17}$ See Elizabeth Wood, The Beautiful Beginnings, The Failure to Learn: FIFTY YEARS OF PUBLIC HOUSING IN AMERICA 2-7 (1982).

1878 F.2d 684 (6th Cir. 1935).

${ }^{19}$ See id. at 687 (stating that the power of eminent domain does not include "the construction of sanitary houses to sell or lease to low-salaried workers or residents of slum districts ${ }^{n}$ ).

${ }^{20}$ Pub. L. No. 75-412, 50 Stat. 888 (codified as amended at 42 U.S.C. $\$ \S 1437-$ 1439 (1988 \& Supp. V 1993)).

${ }^{21}$ Some state courts had already decided that contrary to Louisville, state subdivisions had the power to use their own powers of eminent domain to provide low-cost housing. See, e.g., New York City Hous. Auth. v. Muller, 1 N.E.2d 153, 156 (N.Y. 1936) ("[T] administer it as part of a project conceived and to be carried out in its own interest .... This is ... a public use.").

${ }^{22}$ In addition, the municipality in which the public housing was located and the PHA were required to execute a Cooperation Agreement in which the municipality exempted the PHA from real property taxes. PHAs did contribute payments in lieu of property taxes to the municipality. See 42 U.S.C. $\$ 1437 c(e)(2)$ (1988).

${ }^{23}$ The typical bond had a term of 40 years. In the mid-1980s, the federal government gave loans or grants directly to PHAs instead of requiring them to float bonds. See 42 U.S.C. $\$ 1437 c(a)(2)$ (1988). 
The outbreak of World War II resulted in relatively low levels of public housing being built under the Housing Act of 1937. ${ }^{24}$ Following the war, Congress reenacted the program in the Housing Act of $1949,{ }^{25}$ which also established the Urban Renewal slumclearance program. Today, there exist 1.4 million units of public housing in over ten thousand developments. Over $85 \%$ of this housing was built prior to $1979 .{ }^{26}$

\section{Public Housing and Concentrated Inner-City Poverty}

Although most public housing developments in the United States provide decent and safe homes for their residents, ${ }^{27}$ in many cities public housing has fostered the concentration of poverty in inner-city neighborhoods, sometimes single-handedly creating massive ghettos. ${ }^{28}$ This concentration of poverty is rooted in the structure of the program, federal mandates, the changing demographics of American cities, local mismanagement, and judicial rulings. The federal-local structure of the public housing program, mandated by Congress after the Louisville case, effectively removed the decision of where to locate public housing from the federal government and placed it in the hands of local governments. Rather than public housing being dispersed throughout metropolitan communities, local choice permitted many municipalities, typically those located in the suburbs, to avoid participating in the program.

This bias toward locating public housing in central cities was further strengthened by the inclusion in the Housing Act of 1937 of what has become known as the "equivalent elimination requirement." ${ }^{29}$ This provision mandated that one unit of substandard

${ }^{24}$ From 1937 to $1948,117,000$ units of public housing were built in the United States. See JAmes R. PRescott, Economic AsPects OF Public Housing 24 (1974).

${ }^{25}$ Pub. L. No. 81-171, 63 Stat. 413.

${ }^{26}$ See Michael A. Stegman, The Role of Public Housing in a Revilalized National Housing Policy, in BUILdING Foundations: HOUSING AND FEDERAL POLICY 333, 339 (Denise DiPasquale \& Langley C. Keyes eds., 1990).

${ }^{27}$ See, e.g., National Comm'N ON Severely Distressed Pub. Hous., The Final REPORT 2 (1992) (stating that $6 \%$ of public housing stock is severely distressed); Ronald Jones et al., Problems Affecting Low-Rent Public Housinc Projects 2-3 (1979) (stating that $15 \%$ of the nation's public housing stock can be characterized as "troubled").

${ }^{28}$ For a more detailed analysis of the relationship between public housing and concentrated inner-city poverty, see Michael H. Schill, Distressed Public Housing: Where Do We Go from Here?, 60 U. CHI. L. REV. 497, $501-22$ (1993).

${ }^{29}$ Pub. L. No. 75-412, § 10(a), 50 Stat. at 891-92. 
housing be eliminated for each unit of public housing constructed. ${ }^{30}$ Because most suburbs had little substandard housing, even those that wished to participate in the public housing program were sometimes excluded. ${ }^{31}$

The concentration of public housing in inner cities contributed both directly and indirectly to concentrated poverty. Because land values in cities were usually higher than those for comparable sites at the periphery, much public housing was built on relatively expensive land. To economize on land, urban PHAs tended to build at high densities, often constructing large residential towers. In addition to forcing public housing tenants to live in close proximity to each other, these types of projects often generated a series of problems that led to their abandonment by all but the poorest and least mobile tenants.

High density apartment buildings are now generally thought to be inappropriate for poor families with children. ${ }^{32}$ Elevators break down as a result of heavy usage and insufficient maintenance. In addition, parents find it difficult to monitor the activities of their children when recreation spaces are located at a distance from their apartments. Furthermore, the large volume of residents fosters anonymity, making it difficult for tenants to maintain security and a sense of community. ${ }^{33}$ All of these factors combine to promote vandalism, which further undermines the quality of life in public housing. ${ }^{34}$

After ensuring that most public housing would be built in central cities, Congress also used statutory admissions requirements to fill public housing with extremely poor residents. The 1937

${ }^{30}$ The "equivalent elimination requirement" was enacted at the urging of real estate interest groups that feared competition from publicly supported housing. These interest groups also supported income limitations. See infra notes 35-39 and accompanying text.

${ }^{31}$ See WoOD, supra note 17, at 11 (citing a former federal housing commissioner's testimony that "if there were no slums in the locality, regardless of how acute the housing shortage was, and if we knew that we could not get the equivalent elimination required by the Act, we could not go in there").

${ }_{32}$ In 1968, Congress prohibited the construction of high-rise developments for families with children unless no practical alternative exists. See Housing and Urban Development Act of 1968, Pub. L. No. 90-448, $\$ 207,82$ Stat. 476, 504. But see J.S. Fuerst \& Roy Petty, High-Rise Housing for Low-Income Families, 103 PUB. INTEREST 118, 129-30 (1991) (arguing that high-rise housing is not necessarily inappropriate for families).

${ }^{33}$ See Oscar Newman, Defensible Space 15-18 (1972) (discussing withdrawal from urban life as the result of the physical design of buildings within cities).

s4 See id. 
Housing Act reflects the ambivalence that members of Congress felt over who should live in public housing. ${ }^{35}$ The Act requires that the housing be "within the financial reach of families of low income." "Families of low income" were defined to be those "who are in the lowest income group and who cannot afford to pay enough to cause private enterprise ... to build an adequate supply of decent, safe, and sanitary dwellings for their use. ${ }^{\text {"37 This }}$ legislative mandate that public housing exist to serve the lowest income households was belied by the economics of the program, which required that tenant rents cover most operating costs. ${ }^{38}$ In the end, Congress set income limits for public housing indirectly by requiring that tenants earn no more than five times the rent they paid. ${ }^{39}$

Income limitations grew more stringent in 1949 with the requirement that PHAs establish income ceilings and force those whose incomes exceeded these maximum levels to move out. ${ }^{40}$ Furthermore, Congress mandated that PHAs give preference in admissions to those who were displaced as a result of slum clearance, ${ }^{41}$ thereby assuring the influx of very poor households. Although subsequent statutes permitted PHAs to admit greater proportions of the working poor, ${ }^{42}$ this trend was sharply reversed in 1981 with the congressional mandate that $90 \%$ of all occupants of existing public housing and $95 \%$ of the tenants in newly constructed units earn very low incomes. ${ }^{43}$ As of 1994, these mini-

${ }^{35}$ This ambivalence probably reflected the tension between the desire to help the "worthy poor" as opposed to families on public assistance, on the one hand, and the intent that public housing not compete with market-rate housing, on the other.

${ }^{36}$ Pub. L. No. 75-412, § 2(1), 50 Stat. at 888.

${ }^{37} \S 2(2), 50$ Stat. at 888.

${ }^{38}$ See H.R. Rep. No. 1545, 75th Cong., 1st Sess. 6 (1937) ("It must be recognized, however, that as long as any rent is to be charged in a project, the people who will occupy the dwellings must have some income."); LAWRENCE M. FRIEDMAN, GOVERNMENT AND SLUM HOUSING: A CENTURY OF FRUSTRATION 109 (1968) (quoting Senator Wagner's comment that "obviously this bill cannot provide housing for those who cannot pay the rent minus the subsidy allowed").

${ }^{39}$ See Pub. L. No. 75-412, § 2(1), 50 Stat. at 888.

${ }^{40}$ See Housing Act of 1949, Pub. L. No. 81-171, § 301(8), 63 Stat. 413, 422-23.

${ }^{41}$ See $\$ 302,63$ Stat. at 423 . Congress also prohibited PHAs from discriminating against recipients of public assistance. See $\$ 301,63$ Stat. at 423 .

${ }^{42}$ Indeed, the Housing and Community Development Act of 1974, Pub. L. No. 93$383, \S 201$ (a), 88 Stat. 633,660 (codified at 42 U.S.C. $\$ 1437 d(c)(4)(A)$ (iv)) sought to "avoid concentrations of low-income and deprived families with serious social problems" by eliminating income ceilings.

${ }^{43}$ See Omnibus Budget Reconciliation Act of 1981, Pub. L. No. 97-35, § 323, 95 Stat. 357, 404-05 (codified as amended at 42 U.S.C. $\$ 1437 \mathrm{n}$ (1988)). A very low- 
mum quotas for very low-income households had been slightly reduced to $75 \%$ and $85 \%$, respectively. ${ }^{44}$

Local governments and PHAs have also acted to promote the concentration and isolation of very poor households in public housing through their siting policies and management practices. In the absence of effective federal oversight, ${ }^{45}$ public housing developments were frequently constructed in the least desirable parts of town, often those areas predominantly occupied by racial minorities. For example, in Chicago, local politicians succeeded in obtaining state legislation giving the City Council the right to reject sites proposed by the Chicago Housing Authority. ${ }^{46}$ A custom developed in which individual neighborhoods were permitted to veto the construction of public housing within their borders. ${ }^{47}$ The consequences of this practice are summarized by Arnold Hirsch:

Of the thirty-three projects approved between 1950 and the mid1960s, twenty-five and a "substantial portion" of another were located in census tracts containing a black population in excess of 75\%. Of the remaining seven developments, six were located in areas undergoing racial transition. By the time the projects were actually completed, only one of the thirty-three was situated in an area that was less than $84 \%$ black; and all but seven of the developments, when actually completed, were located in census tracts that were at least $95 \%$ black. $^{48}$

income household has income below $50 \%$ of the area median income. See $\S 322(a)$, 95 Stat. at 400 (codified as amended at 42 U.S.C. $§ 1437$ a (1988)).

14 See Cranston-Gonzalez National Affordable Housing Act, Pub. L. No. 101-625, $\S 511,104$ Stat. 4079, 4194 (1990) (codified at 42 U.S.C. § 1437n (Supp. II 1990 \& Supp. V 1993)).

15 Indeed, in the early years of the program, the federal government instructed PHAs to follow the "neighborhood composition rule," under which the racial composition of public housing developments was supposed to mirror their neighborhoods. See Mittie O. Chandler, Public Housing Desegregation: What Are the Options?, 3 HOUSING POL'Y DEBATE 509, 518 (1992) (noting this federal mandate in the context of examining policy and programmatic options for the desegregation of low-income public housing).

${ }^{16}$ See ARnold R. Hirsch, Making the Second Ghetto: Race \& Housing in Chicago 1940-1960, at 223 (1983).

17 See id. at $240-41$.

${ }^{18}$ Id. at $242-43$. A recent study by Massey and Kanaiaupuni found a significant relationship between the racial composition of Chicago census tracts in 1950 and whether public housing was constructed in that tract. The greater the proportion of blacks in the tract in 1950, the more likely that public housing would be located in that tract by 1970. See Douglas S. Massey \& Shawn M. Kanaiaupuni, Public Housing and the Concentration of Poverty, 74 Soc. SCI. Q. 109, 114-15 (1993) (using statistical projections to examine the premise that public housing represents an important cause of poverty concentration in U.S. cities); see also GREGORY D. SQUIRES ET AL., CHICAGO: 
The geographic limitations on public housing imposed by the political process, together with the city's need to construct a large volume of replacement housing for households displaced by slumclearance activities, led to enormous concentrations of public housing and low-income households in certain Chicago neighborhoods. Similar, if less dramatic patterns were repeated in many other large American cities such as Dallas, Miami, and Philadelphia. ${ }^{49}$

Inefficient management and systematic under-maintenance also contributed to the ghettoization of public housing. The Housing Act of 1937 made no provision for operating expenses or eventual renovation of public housing developments. Instead, these expenses were to be covered by the rents paid by tenants. As the relative income of public housing tenants fell due to inflation, federal tenant admission requirements, and the deindustrialization of central cities, PHAs were hard-pressed to maintain their housing stocks. $^{50}$ The Brooke Amendment, passed by Congress in 1969, brought matters to a head by limiting rents to $25 \%$ of tenants' income. ${ }^{51}$ In the face of financial crises and massive levels of deferred maintenance, Congress enacted a variety of operating and modernization subsidies, none of which have been sufficient to reverse the deterioration of the nation's stock of public housing. According to a recent report prepared for the National Commission on Severely Distressed Public Housing, the amount needed to

RaCe, Class, and the Response to URBan DeCline 102-05 (1987) (describing political decisions to isolate Chicago publichousing). See generally MARTIN MEYERSON \& Edward C. Banfield, Politics, Planning and the Public Interest: The Case of Public Housing IN ChICAGo (1955) (describing the controversies over public housing location in Chicago).

${ }^{49}$ See, e.g., Walker v. HUD, 734 F. Supp. 1289, 1293 (N.D. Tex. 1989) ("From its beginning, the primary purpose of [the Dallas Housing Authority's] public housing program was to prevent blacks from moving into white areas of this city."); JOHN F. BAUMAN, PUBliC HOUSING, RACE, AND RENEWAL: URBAN PLANNING IN PHILADELPHIA 1920-1974, at 169 (1987) ("All of the projects planned and built [in Philadelphia] from 1956 to 1967 were sited in ghetto or 'transitional' neighborhoods."); Raymond A. Mohl, Race and Space in the Modern City: Interstate-95 and the Black Community in Miami, in URBAN POLICY IN TWENTIETH-CENTURY AMERICA 100, 132-33 (Arnold R. Hirsch \& Raymond A. Mohl eds., 1993) (noting that in the 1960s, public housing was built in already segregated areas of Miami).

${ }^{50}$ See RACHel. G. BRATT, Rebuilding a Low-InCOME Housing POLICY 58 (1989) (noting the problems in the public housing financing formula that surfaced in the 1970s).

${ }^{51}$ See Housing and Urban Development Act of 1969, Pub. L. No. 91-152, § 213(a), 83 Stat. 379, 389 (1970). 
modernize existing public housing ranges from $\$ 14.5$ billion to $\$ 29.2$ billion. ${ }^{52}$

Physical deterioration of public housing has also been exacerbated by the managerial inefficiencies of many PHAs. Poor management has frequently been attributable to the absence of incentives to maximize profits as well as to political patronage and corruption. $^{53}$ Although no systematic evaluations of PHA management practices exist, individual accounts of mismanagement are plentiful. Apartments often do not meet local health and safety requirements. ${ }^{54}$ Further decay results from the frequently lengthy periods of time it takes many PHAs to complete even relatively simple repairs. ${ }^{55}$ Long delays in re-renting vacant apartments and in evicting tenants engaged in damaging and unlawful practices lead to vandalism. ${ }^{56}$ In some jurisdictions, these management problems have become so severe that the federal government has placed the PHAs in receivership. ${ }^{57}$

${ }^{52}$ See ICF, INC., The Modernization Needs of Severely Distressed Public Housing, in COMPILATION OF UNEDITED TECHNICAL WORKING DRAFTS PREPARED FOR THE National Commission on Severely Distressed Public Housing as of June 1 , 1993, at 3 (1992) [hereinafter COMPILATION].

${ }^{53}$ See, e.g., Schill, supra note 28, at 497 (noting the frequent accounts of corrupt administrators); Michael H. Schill, Privatizing Federal Low Income Housing Assistance: The Case of Public Housing, 75 CORNELL L. REv. 878, 902-04 (1990) (discussing how the absence of market discipline and the political process may contribute to the increased cost of public housing).

${ }^{54}$ See, e.g., OfFICE OF INSPECTOR GeN., U.S. DeP'T OF Hous. AND URBAN DEv., Philadelphia Housing authority Management and Selected Development OPERATIONS 3 (1992) (finding that of the 87 public housing units inspected, 86 were not in good repair); U.S. GEN. Accounting OfFice, Public Housing: Chicago HOUSING AUTHORITY TAKING STEPS TO ADDRESS LONG-STANDING PROBLEMS 15 (1989) (finding that $93 \%$ of the apartments inspected had "many serious physical problems"); Scott Harper, Auditors Give an "F" for Upkeep: Say City Flunking at Allen Parkway Village, HOUSTON POST, Dec. 18, 1992, at A27, A31 (reporting that none of the units inspected at a Houston public housing development met federal standards).

${ }_{55}$ See, e.g., OFFICE OF INSPECTOR GEN., supra note 54, at 13 (reporting that only about one-half of all reported repair work orders in Philadelphia were completed within the federally prescribed three-day period); Rene Sanchez, D.C. Council Hears Dismal Tales of Public Housing Repair Delays, WASH. POST, Mar. 1, 1992, at B8 (describing "the abysmal state of maintenance in [D.C.'s] 57 public housing complexes").

${ }_{55}$ See, e.g., OFFICE OF INSPECTOR GEN., supra note 54, at 9 (reporting that the Philadelphia Housing Authority has an overall vacancy rate of $20.5 \%$ and that the average period of vacancy for conventional public housing units in the city is $\mathbf{1 5 6 3}$ days); James Lawless, Report Critical of CMHA; Repairs, Spending Come Under Fire, Cleveland Plain Dealer, Oct. 4, 1992, at B1 (stating that a HUD audit found a $31 \%$ vacancy rate in the Cleveland $\mathrm{PHA}$ ).

${ }^{37}$ See Michael deC. Hinds, Public Housing Ills Lead to Questions About H.U.D., N.Y. 
Physical deterioration of public housing, whether caused by insufficient federal subsidies or by local mismanagement, exacerbates the concentration of poverty within its walls. Households with sufficient resources move elsewhere, leaving behind an increasingly impoverished group of tenants. The resulting loss of rent income only intensifies the difficulties PHAs face in maintaining units for those left behind.

Federal court rulings granting tenants procedural protections and HUD regulations implementing these judicial decisions may also have contributed to the concentration of poverty within public housing. In the early years of the program, PHAs had enormous latitude in admission and eviction decisions. ${ }^{58}$ This freedom permitted PHAs to screen out "problem" tenants and quickly evict those who created difficulties. ${ }^{59}$ Beginning in the 1960 s, however, federal courts ruled that PHAs must adopt "ascertainable standards" to guide their admissions process and must accord tenants with a hearing, access to records, and an opportunity to cross-examine witnesses prior to eviction. ${ }^{60}$ Courts did not limit their review of PHA procedures to procedural matters; they also ruled that certain grounds for rejection or eviction, such as illegitimacy and the existence of criminal records, were inappropriate. ${ }^{61}$

TIMES, July 20, 1992, at A8 (noting that since 1989, HUD has taken partial or full control over six PHAs).

${ }^{58}$ This latitude sometimes led PHAs to abuse their discretion. See Charles A. Reich, Individual Rights and Social Welfare: The Emerging Legal Issues, 74 YALE L.J. 1245,1250 (1965). Reich notes that public housing authorities' power to select and evict tenants

can be exercised in a way that is largely discretionary, based in part upon officials' intangible impressions from interviews and home visits . . . . The standards are generally vague, and there are no clearly articulated methods of proof. There may be little in the way of procedure to make certain that the authorities' information is true.

Id.

${ }^{59}$ See Lawrence M. Friedman, Public Housing and the Poor: An Overview, 54 CAL. L. REV. 642, 657 (1966) (stating that housing authorities often screen out "undesirable households" with the aid of social workers).

${ }^{60}$ See, e.g., Thorpe v. Housing Auth., 393 U.S. 268, 283 (1969) (upholding HUD regulation requiring that tenants in federally assisted projects be informed of the reasons for eviction and given the opportunity to make a reply prior to eviction); Escalera v. New York City Hous. Auth., 425 F.2d 853, 862-63 (2d Cir.) (noting that due process is required for terminating tenancies on the ground of nondesirability), cert. denied, 400 U.S. 853 (1970); Holmes v. New York City Hous. Auth., 398 F.2d 262, 264-65 (2d Cir. 1968) (noting that due process is required for tenant admission procedures).

${ }^{61}$ See Thomas v. Housing Auth., 282 F. Supp. 575, 581 (E.D. Ark. 1967) (holding that a housing authority may not exclude on the basis of illegitimacy); NATIONAL 
The resulting loss of PHA freedom to select and evict tenants has contributed to the concentration of poverty within public housing. The ability of PHAs to screen out potentially troublesome tenants has been reduced, as has their power to evict those harmful to the community. ${ }^{62}$ As a result, the quality of life in some public housing developments has deteriorated, causing those residents who possessed sufficient resources to move away and leave behind an increasingly marginalized population.

Recent data confirm the increasing concentration of poverty in public housing. The median income of families living in public housing is extremely low-less than $\$ 6500 .{ }^{63}$ Approximately threequarters of all nonelderly families living in public housing have incomes below the poverty level. ${ }^{64}$ Over half of all residents have not graduated from high school ${ }^{65}$ and a similar proportion receives public assistance. ${ }^{66}$ Longitudinal data demonstrate the increasing concentration of poverty in public housing over the past twenty years. In 1974, just over $1 \%$ of all households living in nonelderly developments earned less than $10 \%$ of the area's median income; this proportion grew to over $19 \%$ in $1991 .^{67}$

In addition to being composed of overwhelmingly poor tenants, public housing is also extremely racially segregated. Two-thirds of all nonelderly families are black and nearly one-fifth are His-

Hous. Law PRoject, HUD Housing Procrams: TeNANTS' Rights 2/42 n.484 (2d ed. 1984) (discussing Tucker v. Norwalk Hous. Auth., Civ. No. B-251 (D. Conn. 1971) (enjoining policy rejecting applicants with a criminal record)).

${ }_{62}$ See J.S. Fuerst \& Roy Petty, Due Process-How Much Is Enough?, 79 PUB. INTEREST 96, 100-01 (1985). Contrary to the assertion of Professor Roisman, see Florence W. Roisman, Intentional Racial Discrimination and Segregation by the Federal Government as a Principal Cause of Concentrated Poverty: A Response to Schill and Wachter, 143 U. PA. L. REv. 1351, 1364 n.52 (1995), we do not equate "problem" tenants with very-lowincome tenants. Instead, we state that current federal laws make it difficult to screen out and evict tenants whose behavior is harmful to the community regardless of their income.

${ }^{63}$ See Connie CASEy, Characteristics of HUD-Assisted Renters and Their UNITS IN 1989, at 68 (1992) (providing a table showing that the median income of households in both family and elderly developments is $\$ 6571$ ); YVES S. DJOKO \& WAyNe SHERwOOD, REPORT No. 92-3: Public Housing DEMOGRAPHICS, 1992, at 24 (1992) (stating that the median gross income of such families is \$5747).

64 See CASEY, supra note 63, at 68.

${ }^{65}$ See U.S. DEP'T OF HOUS. AND URBaN DEV., LITERACY AND EDUCATION NEEDS IN PUBliC AND INDIAN HOUSING DEVELOPMENTS THROUGHOUT THE NATION 5 (1992).

${ }^{66}$ See CASEY, supra note 63 , at 68 (finding that $57 \%$ of all nonelderly families receive welfare or supplemental security income).

${ }^{67}$ See Lawrence J. Vale, Beyond the Problem Projects Paradigm: Defining and Revitalizing "Severely Distressed" Public Housing, 4 HOUSING POL'Y DEBATE 147, 155 (1993). 
panic. ${ }^{68}$ Minority public housing tenants are especially likely to earn extremely low incomes. ${ }^{69}$

\section{An Empirical Analysis of the Relationship Between Public Housing and Neighborhood Poverty Rates}

Although concentrations of poverty within public housing have been well documented, little research has been done to examine the effect of public housing developments on the surrounding neighborhoods. To the extent that public housing generates negative externalities, one would expect it to affect property values and the social composition of the neighborhoods in which it is located. The few studies that have examined the impact of public housing on neighboring property values, however, fail to find a negative effect. $^{70}$

Similarly, three studies which examine the effect of public housing on neighborhood racial or socioeconomic composition reach somewhat contradictory results. Each of these studies test multiple regression models with longitudinal census data for one large city. Ira Goldstein and William Yancey specify two equations in which the proportions of blacks in Philadelphia census tracts in 1970 and 1980 are regressed over several independent variables, including their distance from the city center, the number of industrial jobs within one mile of the tract, the median housing value in 1934, the proportion of blacks in 1950, and whether the tracts contain public housing. ${ }^{71}$ The variable representing the exis-

${ }^{68}$ See CASEY, supra note 63, at 44; Lawrence J. Vale, Occupancy Issues in Distressed Public Housing: An Outline of Impacts on Design, Management and Service Delivery, in COMPILATION, supra note 52, at 17.

${ }^{69}$ See Vale, supra note 68 , at 9 (stating that $25.6 \%$ of black families earn less than $10 \%$ of the area's median income, compared to $13.6 \%$ of white families).

${ }^{70}$ See Hugh O. Nourse, The Effect of Public Housing on Property Values in St. Louis, 39 LAND ECON. 433, 440-41 (1963) (finding that public housing had no effect on property values for two sites but had a positive effect for one site); William A. Rabiega et al., The Property Value Impacts of Public Housing Projects in Low and Moderate Density Residential Neighborhoods, 60 LAND ECON. 174, 178 (1984) (noting that low density public housing developments have a positive, but small, effect on neighboring property values).

${ }^{71}$ See Ira Goldstein \& William L. Yancey, Public Housing Projects, Blacks, and Public Housing in Philadelphia, in HOUSING DESEGREGATION AND FEDERAL POLICY 262-89 (John M. Goering ed., 1986). 
tence of conventional public housing in a tract consistently fails to reach accepted levels of statistical significance. ${ }^{72}$

George Galster and Heather Keeney also examine the effect of subsidized housing on neighborhood racial change in Yonkers, New York from 1970 to $1980 .^{73}$ Their model includes variables measuring the racial composition of census tracts and adjacent tracts, as well as variables measuring the proportion of the population that is over the age of sixty-four, college graduates, and homeowners. Unlike Goldstein and Yancey, Galster and Keeney find a significant relationship between the number of units of subsidized housing and increases in the proportion of black residents. Nevertheless, they report that the magnitude of this relationship is small. ${ }^{74}$

The third study, by Douglas Massey and Shawn Kanaiaupuni, ${ }^{75}$ examines Chicago census tracts to determine whether the existence of public housing constructed between 1950 and 1970 is related to the proportion of families with incomes below the poverty line in 1980. In addition to the public housing variable, their model includes the proportion of blacks and families living in poverty in 1970, the distance of each tract from a public housing project, and the net migration rate from the tract. Massey and Kanaiaupuni find a positive, statistically significant relationship between the existence of public housing in a census tract and the proportion of families in poverty in $1980 .^{76}$

The studies by Goldstein and Yancey and Massey and Kanaiaupuni on the impact of public housing on neighborhood social and racial composition share a common methodological weakness. The independent variable of interest, the existence of public housing in the tract, is a dummy variable taking on the value of " 1 " if public housing exists and " 0 " otherwise. Theory would predict, however, that the size of a public housing development should be important in explaining its impact on the neighborhood in which it is located. If public housing generates negative externalities, extremely small developments are unlikely to exert as much of an effect on their neighborhoods as do large developments. We therefore specify a

72 See id. at 281.

${ }^{73}$ See George Galster \& Heather Keeney, Subsidized Housing and Racial Change in Yonkers, New York, 59 J. AM. PLAN. Ass'N 172 (1993).

${ }^{74}$ See id. at $179-80$.

${ }^{75}$ See generally Massey \& Kanaiaupuni, supra note 48.

${ }^{76}$ See id. at 116-17 (noting that the presence of a housing project increased its 1980 poverty rate by $11 \%$ and finding that the rate of poverty fell steadily as a tract's distance from housing projects increased). 
model in which the quantity of public housing units in a census tract is hypothesized to affect the proportion of poor households in that tract and surrounding tracts.

The data set used in our analysis merges census tract data from the United States Census of Population and Housing for the City of Philadelphia for each decade from 1950 to $1990 .^{77}$ Because census statistics on families earning incomes below the federally prescribed poverty level are unavailable for years prior to 1970 , we use an alternative definition of poverty. A family is classified as poor if its total income is less than one-half of the median income of its metropolitan area. $^{78}$ The dependent variable in our model, NEWPOV, is the ratio of poor to nonpoor families in a census tract.

Levels of poverty in urban neighborhoods are likely to be affected by a variety of socioeconomic and locational influences. In our model, we hypothesize that NEWPOV in any year $(t)$ will be affected by a variety of socioeconomic and locational factors that existed ten years earlier $(t-10)$. For example, we include as independent variables the proportions of the population in the earlier period that were impoverished, unemployed, owner-occupants, and nonwhites. In addition, we include variables to capture how far the census tract is from the central business district and the two major subway lines. A full list of the independent variables contained in our model may be found in Table III. ${ }^{79}$

${ }^{77}$ Because the tract boundaries in Philadelphia were redrawn between the 1950 and 1960 census and again between 1960 and 1970, it was necessary to aggregate some tracts to allow comparisons of similar geographic areas over time. This aggregation of tracts, together with the fact that the Census Bureau suppresses data when a tract has a very small number of residents or dwellings, cause our annual sample sizes to fall below the total number of tracts for each year. To accommodate these different sample sizes, observations were weighted proportionately to the square root of the number of families in the tract.

${ }^{78}$ This definition of poverty coincides with the definition of very low-income households under federal housing law. See 42 U.S.C. $\$ 1437 a(b)(2)$ (Supp. V 1993). Because it was necessary to estimate median metropolitan family income for 1950 , we used an extrapolation based on trends in the ratio of unrelated individuals to families in the city and suburbs as related to trends in relative median incomes.

${ }^{79}$ All continuous variables in Table III with the exception of EDUC, EMPLOY, and MALEMPLOY are expressed in logarithmic form. In addition, because some of the ratios may have zero denominators, we follow the suggestion of Cox by simultaneously weighing the numerator and denominator by $1 / 2 n$. See G.S. MADDALA ET AL., ECONOMETrics 33 (1993) (citing D.R. Cox, ANAlysis Of BINARY DATA 33 (1970)). 
TABLE III

\section{PUBLIC HOUSING LOGIT REGRESSION VARIABLE DEFINITIONS AND DESCRIPTIONS}

\begin{tabular}{|c|c|}
\hline $\begin{array}{l}\text { DEPENDENT } \\
\text { VARIABLE }\end{array}$ & DESCRIPTION \\
\hline NEWPOV & $\begin{array}{l}\text { Ratio of families with incomes } 50 \% \text { below the median } \\
\text { income for the metropolitan area to families with } \\
\text { incomes above this level in census tract }\end{array}$ \\
\hline $\begin{array}{l}\text { INDEPENDENT } \\
\text { VARIABLE* }\end{array}$ & DESCRIPIION \\
\hline POV & $\begin{array}{l}\text { Ratio of families with incomes } 50 \% \text { below the median } \\
\text { income for the metropolitan area to families with } \\
\text { incomes above this level in census tract }\end{array}$ \\
\hline POVSQ & POV squared \\
\hline EDUC & $\begin{array}{l}\text { Median number of school years completed by residents } \\
\text { of census tract }\end{array}$ \\
\hline EMPLOY & $\begin{array}{l}\text { Ratio of persons employed to total population in census } \\
\text { tract }\end{array}$ \\
\hline MALEMPLOY & Ratio of males employed to total males in census tract \\
\hline NONWHITE & $\begin{array}{l}\text { Ratio of nonwhite population to white population in } \\
\text { census tract }\end{array}$ \\
\hline OWNER & $\begin{array}{l}\text { Ratio of owner-occupied housing units to rental housing } \\
\text { units in census tract }\end{array}$ \\
\hline PUBLIC & $\begin{array}{l}\text { Ratio of project-based public housing units to total } \\
\text { occupied housing units that are not project-based } \\
\text { public housing units in census tract }\end{array}$ \\
\hline PUBLICSQ & PUBLIC squared \\
\hline CHPUBLIC & $\begin{array}{l}\text { Increase or decrease in PUBLIC for the ten-year period } \\
\text { immediately preceding the date on which dependent } \\
\text { variable NEWPOV is measured }\end{array}$ \\
\hline CHPUBLICSQ & CHPUBLIC squared \\
\hline DBIGPUBLIC & $\begin{array}{l}\text { Distance (in miles) to nearest public housing develop- } \\
\text { ment with more than } 600 \text { housing units }\end{array}$ \\
\hline DCBD & Distance (in miles) to central business district \\
\hline DSUBWAY & $\begin{array}{l}\text { Distance (in miles) to the nearer of the Broad or Market } \\
\text { Street subway lines }\end{array}$ \\
\hline YEAR70 & Dummy variable for observations in 1970 \\
\hline YEAR80 & Dummy variable for observations in 1980 \\
\hline YEAR90 & Dummy variable for observations in 1990 \\
\hline
\end{tabular}


Of particular interest for our study is the effect of three variables relating to the existence of public housing in a census tract. ${ }^{80}$ The first variable, PUBLIC, represents the ratio of projectbased public housing units in a census tract to all housing units that are not project-based public housing. ${ }^{81}$ For each observation, PUBLIC is measured ten years prior to the dependent variable NEWPOV. To capture the incremental effect of changes over the ten years in the proportion of public housing in a neighborhood, we include the independent variable CHPUBLIC. Finally, we examine the effect of proximity to especially large public housing developments by including the variable DBIGPUBLIC, which measures the distance in miles from the center of a census tract to the nearest public housing development with more than six hundred apartments. If public housing is related to increased levels of poverty in urban neighborhoods, we expect the coefficients of PUBLIC and CHPUBLIC to be positive and statistically significant and DBIGPUBLIC to be negative and statistically significant.

Table IV presents the results of our logit regression. Alternative models were also specified and tested with similar results. Most of the independent variables have the expected signs and many are statistically significant. Neighborhoods composed of disproportionately high numbers of poor families and persons with low levels of education are more likely to experience increased levels of poverty ten years later. Although the variables representing rates of unemployment and owner-occupancy have signs consistent with economic theory, they are not statistically significant.

${ }^{80}$ Throughout this analysis, the three public housing variables exclude public housing specifically reserved for the elderly.

${ }^{81}$ To make this ratio approximate the actual ratio of families in public housing to families not in public housing as closely as possible, we make two adjustments. First, we count the few zero-bedroom (efficiency) public housing units in Philadelphia as one-half units, since many will be occupied by single persons and thus, are not counted as families in the census. Second, we deflate the total number of units in each project by a factor of .91 , which was the official occupancy rate of public housing in Philadelphia as of December 1993. 
TABLE IV

Public Housing Logit REgRession RESUlts

(DEPENDENT VARIABLE-NEWPOV)

\begin{tabular}{|l|c|c||}
\hline \multicolumn{1}{|c|}{ VARIABLE } & COEFFIENT & STANDARD ERROR \\
\hline \hline INTERCEPT & $1.5080^{* *}$ & \\
\hline POV & $0.8008^{* *}$ & 0.916 \\
\hline POVSQ & $-0.0742^{* *}$ & 3.157 \\
\hline EDUC & $-0.1352^{* *}$ & 0.109 \\
\hline EMPLOY & 0.0226 & 0.068 \\
\hline MALEMPLOY & -0.3539 & 0.109 \\
\hline NONWHITE & $0.0138^{\circ}$ & 3.543 \\
\hline OWNER & -0.0224 & 1.124 \\
\hline PUBLIC & $0.2219^{* *}$ & 1.942 \\
\hline PUBLICSQ & $-0.0159^{* *}$ & 20.757 \\
\hline CHPUBLIC & $0.269 *^{* *}$ & 0.987 \\
\hline CHPUBLICSQ & $-0.0270^{* *}$ & 6.008 \\
\hline DBIGPUBLIC & $-0.1382^{* *}$ & 0.555 \\
\hline DCBD & $0.2034^{* *}$ & 0.513 \\
\hline DSUBWAY & $-0.2593^{* *}$ & 0.575 \\
\hline YEAR70 & $0.2338^{* *}$ & 0.444 \\
\hline YEAR80 & $0.6108^{* *}$ & 0.424 \\
\hline YEAR90 & $0.5341^{* *}$ & 0.410 \\
\hline N & 1298 & \\
\hline
\end{tabular}

* Significant at $\mathbf{5 \%}$ level

** Significant at $1 \%$ level 
All three public housing variables have the hypothesized signs and are statistically significant. Holding all other factors constant, higher concentrations of public housing in a neighborhood (PUBLIC and CHPUBLIC) are positively related to increased neighborhood poverty rates in the city of Philadelphia. ${ }^{82}$ In addition, as the distance of a census tract from a large public housing development (DBIGPUBLIC) increases, its poverty rate declines. ${ }^{83}$

The importance of the relationship between concentrations of public housing and increased neighborhood poverty rates cannot be interpreted solely from the variable coefficients and significance levels reported in Table IV. Instead, their significance depends upon the values of the other variables contained in the logit equation. We therefore use the coefficients obtained in Table IV to explore the effect of increased proportions of public housing on neighborhood poverty rates. For variables other than the proportion of project-based public housing units in the census tract ten years earlier (PUBLIC), we use mean sample values. ${ }^{84} \mathrm{We}$ can thereby simulate the increase in poverty attributable to changes in PUBLIC by selecting alternative values of the variable.

The results of the simulation, reported in Table V, suggest that, at least in Philadelphia, increased levels of public housing in a neighborhood have a dramatic effect on neighborhood poverty rates. An average neighborhood with no public housing units would be expected to have a $13 \%$ poverty rate. The poverty rate would

${ }^{82}$ The negative and statistically significant coefficients for PUBLICSQ and CHPUBLICSQ suggest that as public housing concentrations increase, their positive effect on poverty rates does not increase in a linear fashion.

${ }^{83}$ It is possible, as Galster suggests, that increasing concentrations of poverty within public housing itself may have affected our results with respect to the PUBLIC and CHPUBLIC variables. See George C. Galster, A Response to Schill and Wachter's The Spatial Bias of Federal Housing Law and Policy, 143 U. PA. L. REv. 1343, 1344-45 (1995). Nevertheless, it is unlikely that increased proportions of poor people in public housing would have had much of an effect on DBIGPUBLIC because for most census tracts it measured the effect of proximity to public housing located in another census tract. Galster also hypothesizes that our results might be explained by the fact that public housing developments had high occupancy rates and were located in areas that had high levels of private market housing abandonment. See id. Although it is possible that our results might have been affected by this combination of factors, it is unlikely that it would explain the magnitude of our empirical result. See infra text accompanying note 85. Furthermore, vacancy rates in several of the public housing developments in Philadelphia during the period from 1950 to 1990 have been extremely high. To the extent that private market disinvestment occurs in neighborhoods with public housing, this deterioration may be caused by the negative externalities of public housing itself.

${ }^{84}$ For CHPUBLIC, we use the value "0." 
climb to $31.8 \%$ if the neighborhood had an average proportion of public housing (for census tracts with public housing) in Philadelphia. For communities in the highest quintile of public housing concentration, the poverty rate would jump to $52.1 \%$, a value four times as high as a neighborhood with no. project-based public housing. ${ }^{85}$

\section{TABLE V}

\section{Public Housing Simulation}

\begin{tabular}{|c|c|c|}
\hline PUBLIC $^{86}$ & QUINTILE & PREDICTED POVERTY RATE \\
\hline 0 & 0 & $13.0 \%$ \\
\hline 0.112 & $20 \%$ & $25.2 \%$ \\
\hline 0.136 & $40 \%$ & $27.1 \%$ \\
\hline 0.190 & $50 \%$ & $31.8 \%$ \\
\hline 0.247 & $60 \%$ & $35.9 \%$ \\
\hline 0.420 & $80 \%$ & $52.1 \%$ \\
\hline
\end{tabular}

Our results for Philadelphia are generally consistent with Massey's and Kanaiaupuni's findings for Chicago. ${ }^{87}$ These results support the hypothesis that project-based public housing generates a negative spillover effect in urban neighborhoods. Whether our findings and those of Massey and Kanaiaupuni are generalizable to all cities, or even all large cities, must await further empirical investigation. Certain factors may distinguish Philadelphia and

85 These results are not attributable to the increased number of poor people living in the public housing itself. We control for this effect by including in the model the variables POV and CHPUBLIC. Professor Roisman's observation that our results may be attributable to the city locating public housing in neighborhoods that would be subject to public sector disinvestment is another possible interpretation of these results. See Roisman, supra note 62, at 1368-69. Unfortunately, given date limitations, we cannot control for this possible cause in our model.

${ }^{86}$ PUBLIC represents the ratio of project-based public housing units to total occupied housing units that are not project-based public housing units in a census tract.

${ }^{87}$ See Massey \& Kanaiaupuni, supra note 48, at 114-19 (finding that the existence of public housing in Chicago is related to increased neighborhood poverty rates). 
Chicago. Historical accounts have documented that decisions about locating public housing in Chicago and Philadelphia were subject to much political interference and controversy. ${ }^{88}$ In addition, public housing authorities in both cities have experienced severe management problems over the past two decades. ${ }^{89}$

\section{B. Federal Mortgage Assistance Programs}

In addition to providing subsidies for the construction of lowincome rental housing, the federal government has actively promoted home ownership among the working poor and the middle class through mortgage assistance programs. These programs have sometimes had the effect of destabilizing inner-city communities and contributing to their transformation into ghettos. In this section, we examine how two federal mortgage assistance programs, which were enacted for very different purposes, had the effect of contributing to neighborhood destabilization and concentrated inner-city poverty.

\section{The FHA Mortgage Insurance Program}

One of the first interventions by the federal government in the home loan mortgage market was the creation of the Home Owners Loan Corporation (HOLC) in $1933 .^{90}$ Prior to the 1930 s, most mortgage loans were nonamortizing, short duration debt obligations, typically with five- to ten-year terms. During the Great Depression, financial instability caused many American homeowners to default on their mortgage loans and threatened many more with future default and foreclosure. The HOLC was created to refinance these loans. ${ }^{91}$ From July 1933 to June 1935, over one million loans, $10 \%$ of all residential loans then outstanding, were refinanced

${ }^{88}$ See, e.g., BAUMAN, supra note 49 , at $167-74$ (describing how blacks came to occupy a disproportionate share of public housing in Philadelphia); SQUIRES ET AL., supra note 48, at 93-126 (describing how institutional decision-makers influenced the kinds and location of public housing to be developed in Chicago).

${ }^{89}$ See supra notes 53-57 and accompanying text.

${ }^{90}$ See Home Owners' Loan Act of 1933, Pub. L. No. 73-43, ch. 64, § 4, 48 Stat. $128,129-32$, repealed by Housing Amendments of 1953, Pub. L. No. 83-94, § 21(a), 67 Stat. 121, 126.

${ }^{91}$ See NAThaniel S. KeIth, Polmtics AND The Housing CRisis Since 1930, at 24 (1973) (noting that the Roosevelt Administration and Congress enacted this legislation to rescue beleaguered homeowners from foreclosure and to permit lending institutions to make new mortgages). 
by the HOLC. ${ }^{92}$

One of the most important contributions of the HOLC was the uniformity it promoted among financial institutions engaged in residential lending. In addition to introducing the fixed-rate, selfamortizing long-term mortgage loan, the HOLC also created uniform appraisal standards throughout the country. HOLC appraisers divided cities into districts, which they rated in terms of potential risk. Areas with even relatively small black populations were usually given the lowest rating indicating a high-risk of default. One study of HOLC ratings in the St. Louis and Newark metropoli$\tan$ areas found that the standards used by HOLC appraisers systematically favored suburban neighborhoods over those in the central city, even those inner-city neighborhoods with relatively new and desirable housing. ${ }^{93}$

The antiurban underpinnings of the appraisal standards promulgated by the HOLC particularly harmed cities because they influenced the operation of one of the most important federal programs of the past century-the mortgage insurance program of the Federal Housing Administration (FHA). ${ }^{94}$ In 1934, Congress established the FHA and empowered it to guarantee home loan mortgages. The effect of the federal loan guarantee was enormous. Lenders, jittery after years of high rates of loan defaults and foreclosures, could originate home loans free from the risk of loss. By 1972, the FHA had insured eleven million home purchase mortgage loans and twenty-two million home improvement loans. ${ }^{95}$

In several respects, the FHA mortgage insurance program contributed to the decline of inner cities. Program guidelines disfavored "crowded neighborhoods" and "older properties," both of which were much more prevalent in cities than in the newly forming suburbs. ${ }^{96}$ For a time, minimum lot size and setback requirements disqualified row houses, a staple in many urban areas such as Baltimore and Philadelphia. ${ }^{97}$

${ }^{92}$ See Kenneth T. Jackson, Race, Ethnicity, and Real Estate Appraisal: The Home Owners Loan Corporation and the Federal Housing Administration, 6 J. URB. HIST. 419, 421 (1980) (stating that the HOLC covered "one-tenth of all owner-occupied, nonfarm residences").

${ }^{93}$ See id. at 425,428 (describing the higher ratings given to nonblack suburbs in St. Louis and Newark, respectively).

${ }^{94}$ See id. at 430 ("HOLC appraisal methods ... were adopted by the FHA.").

${ }^{95}$ See id. at 432.

${ }^{96} \mathrm{Id}$. at 435 (" $[\mathrm{P}] \mathrm{rospective} \mathrm{buyers} \mathrm{could} \mathrm{avoid} \mathrm{many} \mathrm{of} \mathrm{these} \mathrm{[problems]} \mathrm{.} \mathrm{.} \mathrm{by}$ locating in peripheral sections.").

${ }^{97}$ See Arnold R. Hirsch, With or Without Jim Crow: Black Residential Segregation in 
Perhaps of even greater consequence, FHA appraisal standards emulated HOLC guidelines and discouraged lending in areas where blacks lived. The FHA underwriting manual warned against making loans in areas with "inharmonius racial groups" ${ }^{\text {98 }}$ and instructed lenders that

[a]reas surrounding a location are [to be] investigated to determine whether incompatible racial and social groups are present, for the purpose of making a prediction regarding the probability of the location being invaded by such groups. If a neighborhood is to retain stability, it is necessary that properties shall continue to be occupied by the same social and racial classes. A change in social or racial occupancy generally contributes to instability and a decline in values. ${ }^{99}$

The FHA also recommended that municipalities enact racially restrictive zoning ordinances as well as covenants running with the land prohibiting black owners. ${ }^{100}$

Little careful empirical evidence exists to document the effects of FHA-sponsored "redlining"101 of central city communities.

the United States, in URBAN POLICY IN TWENTIETH CENTURY AMERICA, supra note 49, at 65, 86-87 (noting that "narrow lots" made it more difficult for row houses in Philadelphia and Baltimore to meet the requirements for FHA loans). In addition, FHA programs systematically favored owner-occupied homes over multifamily rental apartment buildings. Because cities had much larger rental housing stocks than suburbs, this bias harmed central cities. See MARK I. GelfaNd, A Nation OF CITIES: THE FEDERAL GOVERNMENT AND URBAN AMERICA, 1933-1965, at 217 (1975) ("[T]he FHA also cast a jaundiced eye at the predominant form of central city accommodations: rental housing. The agency considered rental housing, in comparison to private home construction, a very risky form of investment.").

${ }^{98}$ Gary Orfield, Federal Policy, Local Power, and Metropolitan Segregation, 89 POL. SCI. Q. 777, 786 (1975) (quoting FHA Underwriting Manual).

${ }_{99}$ DenNis R. Judd, THE POLITICS OF AMERICAN CITIEs: PRIVATE POWER AND Public POLICY 281 (1979) (citation omitted) (quoting FHA Underwriting Manual).

${ }^{100}$ See GELFAND, supra note 97, at 220 (" $[$ The] FHA helped perfect [racially restrictive covenants] and virtually made them mandatory."). Racial zoning ordinances were invalidated by the Supreme Court in Buchanan v. Warley, 245 U.S. 60, 82 (1917) (overturning a municipal ordinance forbidding black households from moving into residences where the majority of households are white). Racially discriminatory covenants were held unenforceable in Shelley v. Kraemer, 334 U.S. 1, 23 (1948) (holding that a state court's enforcement of a covenant brought the action within the scope of state action and thus was unconstitutional).

${ }^{101}$ Redlining obtains its name from the practice of FHA underwriters' circling in red areas of the city that were bad credit risks. See NATIONAL COMM'N ON URBAN PROBLEMS, BUILDING THE AMERICAN CITY 101 (1969) ("There was evidence of a tacit agreement among all groups-lending institutions, fire insurance companies, and FHA-to block off certain areas of cities within 'red lines,' and not to loan or insure within them."). 
However, one study by Kenneth Jackson demonstrates that although many more single-family homes were constructed in St. Louis than in its surrounding municipalities, properties in the suburbs received five times the amount of mortgage insurance as did those in the city. ${ }^{102}$ Hirsch similarly reports that one-half of Detroit and onethird of Chicago were excluded from the program. ${ }^{103}$

FHA redlining practices may have contributed to the concentration of poverty in American cities in several ways. First, the bias of the program toward lending in the suburbs, as compared to the cities, encouraged middle-income households to leave the city and exacerbated the income and fiscal disparities between urban and suburban municipalities. ${ }^{104}$ Second, the racially discriminatory underwriting practices engaged in by the FHA promoted racial segregation in American cities and contributed to the creation of urban ghettos. ${ }^{105}$ Lastly, the unavailability of mortgage capital for purposes of home improvement or home purchase in inner-city neighborhoods may have contributed to the disinvestment in housing and decline in property values experienced by most American cities in the second half of the twentieth century. ${ }^{106}$

102 This relationship exists regardless of whether mortgage insurance is measured in the aggregate, per capita, or by the number of mortgages insured. See Jackson, supra note 92 , at 442.

${ }^{103}$ See Hirsch, supra note 97, at 86. Similar redlining of communities inhabited by racial minorities took place in Philadelphia. See CAROLYN ADAMS ET AL., PHILADELPHIA: NeIGHBORHOODS, Division, AND CONFLICT IN A POSTINDUSTRIAL CITY 79-81 (1991).

104 See Paul Kantor, The Dependent City: The Changing Political Economy OF URBAN AMERICA 200 (1988) (stating that FHA policies "virtually ensured that most FHA-insured properties would be in suburbia rather than in central cities"); Bernard J. Frieden, Housing and National Urban Goals: Old Policies and New Realities, in THE METROPOLITAN ENIGMA: INQUIRIES INTO THE NATURE AND DIMENSIONS OF AMERICA'S "URBAN CRISIS" 159, 184-85 (James Q. Wilson ed., 1968) (indicating that FHA and other federal programs favored growth of suburbs). The "flight" to the suburbs that has occurred in many American metropolitan areas since the end of World War II was also heavily influenced by consumer preferences, technological changes in transportation and manufacturing processes, and federal subsidies for highway construction. For a thorough analysis of the causes of metropolitan decentralization, see generally KENNETH T. JACKSON, CRABGRASS FRONTIER: THE SUBURBANIZATION OF THE UNITED STATES (1985).

105 See Daniel R. Fusfeld \& Timothy Bates, The Political Economy of the URBAN GHETTO 43 (Susan H. Wilson ed., 1984) (stating that FHA policies "amounted to a direct federal endorsement of residential segregation" ${ }^{n}$ ); Orfield, supra note 98 , at 789 (" $[T]$ he federal government was a powerful force for segregation.").

${ }^{106}$ Surprisingly, however, no study has carefully documented the causal relationship between redlining and disinvestment. Nevertheless, most urban commentators and policymakers assume, based upon anecdotal evidence, that the link exists. See 


\section{The Section 235 Homeownership Assistance Program}

In part to undo the damage created by FHA mortgage redlining in many urban neighborhoods, Congress enacted the Section 235 Homeownership Assistance Program in 1968. ${ }^{107}$ Section 235 was designed to make homeownership feasible for lower-income households. In addition to providing mortgage insurance for the purchase of one- to four-family homes, the federal government authorized down payments as low as $\$ 200$ and subsidized the interest paid by qualified low-income homebuyers on their mortgage loans. ${ }^{108}$ These subsidies reduced interest rates to as low as $1 \%$ per year. ${ }^{109}$

Section 235 was designed to make capital more available to lower-income urban homebuyers. From 1969 to 1979, approximately 500,000 homes were purchased under the program. ${ }^{110}$ Nevertheless, in several cities, rather than stabilizing inner-city communities, Section 235 promoted rapid neighborhood racial transition and, in some instances, decline. In some communities, the sudden availability of mortgage capital fueled "blockbusting. ${ }^{\text {111 }}$ Realtors would sell a few homes to minority purchasers and spread the rumor that the neighborhood would soon become entirely black to set off a wave of panic selling. Whites would then sell their homes at artificially low prices, frequently to the real estate agents themselves, who would turn around and sell them to nonwhites at inflated values. Neighborhoods changed from all white to virtually all black in a matter of months. ${ }^{112}$

ERIC H. Monkronen, America Becomes URBan: The Development of U.S. CTries \& Towns 1780-1980, at 204 (1988) (stating that FHA policies result in "neighborhood[s] perceived by lenders as risky to in fact become risky, while those perceived as solid become even more solid"); NATIONAL COMM'N ON URBAN PROBLEMS, supra note 101, at 101 ("The net result, of course, [of FHA redlining] was that the slums and the areas surrounding them went downhill farther and faster than before.").

${ }^{107}$ Housing and Urban Development Act of 1968, Pub. L. No. 90-448, § 235, 82 Stat. 476, 476-77, repealed by Pub. L. No. 100-242, § 401(d), 101 Stat. 1898, 1899 (1988).

${ }^{108}$ See Susan M. Wachter, The 1968 Congressional FHA Amendments to the National Housing Act: Their Impact on Urban Areas, in THE URBAN IMPACTS OF FEDERAL POLICIES 426, 427-28 (Norman J. Glickman ed., 1980); Paul Graeser \& Martin Williams, The Economics of Mortgage Foreclosures Under FHA Section 235(i), 5 URB. ANALYSIS 275, 276 (1978).

${ }^{109}$ See BRATT, supra note 50, at 131.

${ }^{110}$ See R. Allen Hays, The Federal Government \& URBan Housing: IDEOLOGY \& Change in Public Policy 116 (1985).

${ }^{111}$ Id. at 114.

112 See Martin Mayer, The Builders: Houses, People, Neighborhoods, 
In addition to promoting racial turnover, excessively high loanto-value ratios, independently and in conjunction with fraudulent practices by real estate entrepreneurs and inept administration of the program by HUD, contributed to community disinvestment. In several cities, particularly Detroit, Chicago, and St. Louis, local real estate investors bribed FHA appraisers to overlook structural flaws and inflate the values of homes sold to Section 235 participants. Because purchasers were required to put very little of their own money at risk, ${ }^{113}$ the investors could sell the homes at inflated prices. As homebuyers learned that their homes had major structural defects and that the values of their homes were less than their outstanding mortgage balances, they abandoned the dwellings rather than invest money that they did not have in repairs. ${ }^{114}$ By 1979 , over ninety thousand homes, or approximately $18 \%$ of the dwellings subsidized under Section 235 were assigned to HUD or foreclosed. ${ }^{115}$ In some instances, entire neighborhoods were blighted. ${ }^{116}$

GOVERNMENTS, MONEY 164-65 (1978); Calvin Bradford, Financing Home Ownership: The Federal Role in Neighborhood Decline, 14 URB. AFF. Q. 313, 325-29 (1979).

113 Indeed, in some instances, the down payments were provided by the real estate investors, themselves. See MAYER, supra note 112, at 165.

${ }^{114}$ For descriptions of the abuses under the Section 235 Homeownership Program, see Brian D. Boyer, CrTIes Destroyed for Cash: The FHA Scandal at HUD (1973); HAYS, supra note 110, at 112-16; U.S. GEN. ACCOUNTING OFFICE, WEAKNESSES IN ADMINISTRATION OF THE PROGRAM TO CORRECT DEFECTS IN HOUSING INSURED UNDER THE SECTION 235 PROGRAM (1975); The Bankruptcy of Subsidized Housing, BUS. WK., May 27, 1972, at 42.

${ }^{115}$ See HAYS, supra note 110 , at 116 . High rates of foreclosure and abandonment were exacerbated by the way the design of the program affected the incentives of mortgagees. Because the interest rate on FHA loans was typically set below the market interest rate, lenders charged several points at the time the loan was originated. Prepayment of the loan, through quick foreclosure following default, would therefore increase the mortgagee's overall rate of return. See Wachter, supra note 108 , at 433 . In some instances, however, quick foreclosure and resale was inhibited by federal forbearance regulations. These delays sometimes resulted in waste of the property, abandonment, and vandalism. See id. at 433-34.

${ }^{116}$ See, e.g., BOYER, supra note 114, at 141-63, 176-79, $197-205$ (describing effects on communities in Chicago, Detroit, and Philadelphia); JOE T. DARDEN ET AL., DETROIT: RACE AND UNEVEN DEVELOPMENT 182 (1987) (describing residential decay in "vast stretches" of Detroit caused by Section 235 foreclosures and abandonments); LAWRENCE J.R. HERSON \& JOHN M. BOLLAND, THE URBAN WEB: POLITICS, POLICY, AND THEORY 293-94 (1990) (describing the effect of Section 235 program on neighborhoods in Chicago); Bradford, supra note 112, at 329 (describing effects in Chicago). The negative impact of the Section 235 program on neighborhoods in certain cities does not necessarily mean that the net effect of the program was negative. Some analysts have suggested that despite its problems, the Section 235 program had beneficial effects for America's poor. See ANTHONY DOWNS, FEDERAL 


\section{Current Housing LAW AND Policy}

Although public housing production in the United States has declined to minimal levels, several elements of federal housing law and policy continue to promote the concentration of poverty in inner-city neighborhoods. In this Part, we describe how current laws governing the public housing program continue to concentrate poverty in inner-city neighborhoods. In addition, we examine the locational biases that may result from laws designed to increase the flow of mortgage funds to inner-city communities.

\section{A. Public Housing}

In 1992, a report prepared for the National Commission on Severely Distressed Public Housing revealed that over 5\% of the nation's stock of public housing required renovations that would cost over $\$ 40,000$ per unit. ${ }^{117}$ Congress responded to the Commission's recommendations by enacting a program that would fund renovation of some severely distressed public housing developments, even if the cost of the renovation exceeded the cost of new construction. ${ }^{118}$ This program reflects the congressional insistence that the stock of public housing not be diminished. Indeed, since 1987, Congress has insisted that before public housing may be demolished, each unit must be replaced on a one-for-one basis with either new public housing or other project-based subsidized apartments. ${ }^{119}$

The effects of the one-for-one replacement requirement have been pernicious for many inner-city communities. PHAs, lacking the money to build new units or renovate existing developments,

HOUSING SUBSIDIES: HOW ARE THEY WORKING? 51, 64-65 (1973).

117 See ICF, INC., supra note 52, at 3.

${ }^{118}$ See Housing and Community Development Act of 1992, Pub. L. No. 102-550, $\S 111,106$ Stat. 3672,3687 (codified at 42 U.S.C. $\S 5301$ (1988 \& Supp. V 1993)). For a critique of policies that would renovate severely distressed public housing developments, see Schill, supra note 28, at 522-43.

119 See Housing and Community Development Act of 1987, Pub. L. No. 100-242, $\S 121$ (b), 101 Stat. 1815, 1837 (1989) (codified at 42 U.S.C. \$ 1437p (1984 \& Supp. $\mathrm{V}$ 1993)). In very limited circumstances, demand-oriented housing subsidies, such as housing certificates, may be used as replacement housing. Before the Secretary of HUD may approve a replacement plan including demand-oriented assistance, however, he must certify that replacement with supply-oriented assistance is not feasible and that the supply of housing in the area will remain sufficient for certificate holders throughout the period in which they will receive assistance. See id. These legislative impediments have made replacement plans with demand-oriented assistance impractical. See Schill, supra note 28 , at 542. 
have often been forced to retain deteriorated or vacant projects rather than demolish them. ${ }^{120}$ These developments blight the communities in which they are located and provide a home for illegal activities such as prostitution and drug dealing. ${ }^{121}$

Tenant admission rules continue to ensure that public housing developments will be home to an overwhelmingly poor and marginalized population. Under federal law, all households that earn under $80 \%$ of their metropolitan area's median income are eligible for public housing. ${ }^{122}$ Nevertheless, between $75 \%$ and $85 \%$ of all public housing units must be reserved for very lowincome households, those who earn less than $50 \%$ of median income. ${ }^{123}$ Furthermore, one-half of all public housing units must be filled according to federally prescribed preference rules. These

${ }^{120}$ Indeed, in several cities, tenants have brought suit against PHAs, charging them with de facto demolition. Several federal courts have held that tenants may challenge PHAs under the United States Housing Act for letting projects deteriorate to the point at which they are uninhabitable. See, e.g., Velez v. Cisneros, 850 F. Supp. 1257, 1270 (E.D. Pa. 1994) (holding that tenants have a private right of action against HUD for de facto demolition); Henry Horner Mothers Guild v. Chicago Hous. Auth., 824 F. Supp. 808, 819 (N.D. Ill. 1993) (same); Gomez v. Housing Auth. of El Paso, 805 F. Supp. 1363, 1374-75 (W.D. Tex. 1992) (same), aff'd sub nom., Gomez v. City of El Paso, 20 F.3d 1169 (5th Cir.), cert. denied, 115 S. Ct. 198 (1994); Concerned Tenants Ass'n of Father Panik Village v. Pierce, 685 F. Supp. 316, 321 (D. Conn. 1988) (same).

Even those PHAs with sufficient funds to demolish old units of public housing and construct replacement housing are frequently stymied by community opposition and federal regulations on the siting of subsidized housing. Residents of neighborhoods with little or no subsidized housing typically fight the introduction of low and moderate income housing through political action and litigation. See, e.g., Project B.A.S.I.C. v. Kemp, 776 F. Supp. 637, 644 (D.R.I. 1991) (denying a motion for summary judgment in a lawsuit challenging replacement housing on the ground that it would be constructed in areas of minority concentration), rev'd, $947 \mathrm{~F} .2 \mathrm{~d} 11$ (1st Cir. 1991); George Judson, Uproar in New Haven on Public Housing Role, N.Y. TIMES, Sept. 30, 1991, at B1 (describing community opposition to PHA purchasing homes as replacement housing). In addition, HUD regulations provide that most federally subsidized housing, including housing built to replace demolished public housing developments, may not be constructed in areas of minority concentration or in neighborhoods containing an "undue concentration" of persons living in poverty. See 24 C.F.R. $\$ \S 770.101-.105,882.708(c), 941.202(c), 970.11(h)$ (1993). Therefore, replacing demolished public housing in neighborhoods that already contain large proportions of poor or minority households is often also impossible.

${ }^{121} \mathrm{See}$ Testimony of Judy A. England-Joseph, U.S. Gen. Accounting Office, Before House Committee on Government Reform and Oversight (Feb. 22, 1995) (on file with authors); Bruce Alpert, Repair Costlier than Rebuilding, TIMES-PICAYUNE (New Orleans), Mar. 23, 1994, at A1.

${ }^{122}$ See 42 U.S.C. $\S \S 1437 \mathrm{a}(\mathrm{b})(2), 1437 \mathrm{~d}(\mathrm{c})$ (1988).

${ }^{123}$ See $\S 1437 \mathrm{a}(\mathrm{b})(2)$ ('t [V]ery low income families' means lower income families whose incomes do not exceed 50 per centum of the median family income for the area ...."). 
regulations grant priority in admissions to particularly needy households such as those occupying substandard housing and those composed of homeless families. ${ }^{124}$

Federal rules governing the computation of rents continue to promote the concentration of poverty in public housing by creating disincentives for residents who are unemployed to obtain work and by discouraging those who do work from remaining in public housing. ${ }^{125}$ Because the rents paid by tenants are set at $30 \%$ of their incomes, those who find jobs face an implicit tax of approximately one-third of their earnings. When combined with the loss of social services and health care benefits that frequently accompany the transition to employment for poor people, this increase in rent may provide a substantial disincentive to join the labor force. ${ }^{126}$ For those tenants who do take jobs, $30 \%$ of their income in many instances exceeds the fair market value of their apartments. ${ }^{127}$ Rather than pay more than their apartments are worth, these tenants leave public housing, further intensifying the concentration of poverty within its walls. ${ }^{128}$

\section{B. Community Reinvestment Act}

In 1991 and 1992, reports that racial and ethnic minority home purchasers were significantly more likely than whites to be rejected when they applied for home mortgage loans shook the housing policy and finance communities. One report by Glenn Canner ${ }^{129}$

${ }^{124}$ See $\S 1437 \mathrm{~d}(\mathrm{c})(4)(\mathrm{A})(\mathrm{i})-(\mathrm{ii})$.

${ }^{125}$ See U.S. Dep't of Hous. and Urban Dev., Explanation and Justification for the Housing Choice and Community Investment Act of 1994, in Statements on Introduced Bills and Joint Resolutions, 140 CONG. REC. S4835, S4838 (daily ed. Apr. 26, 1994) [hereinafter HUD Document] (discussing the effect of current federal rent computation rules).

${ }^{126}$ See id. at $\mathbf{S} 4845-46$ (discussing the disincentives of the $30 \%$ method).

${ }^{127}$ See id. (discussing the unfairness of using the $30 \%$ method when this exceeds the value of the housing).

${ }^{128}$ In 1992, Congress authorized PHAs to establish ceiling rents for their housing stocks. These ceiling rents, however, could be no less than the amount of debt service and operating expenses attributable to units of similar size in developments owned by the PHAs. See Pub. L. No. 102-550 § 102(a), 106 Stat. 3672, 3683 (1992) (codified as amended at 42 U.S.C. § 1437a(a)(2)(A) (1988 \& Supp. V 1993)). Recent Clinton Administration proposals to liberalize the rent setting mechanisms of PHAs argue that the existing ceiling rent formula still produces a rent that in many instances is higher than the units' fair market values. See HUD Document, supra note 125 , at $\mathrm{S} 4846$.

${ }^{129}$ See generally Glenn B. Canner, Home Mortgage Disclosure Act: Expanded Data on Residential Lending, 77 Fed. Res. Bull. 859 (1991). 
analyzed data disclosed by financial institutions under the Home Mortgage Disclosure Act of 1975 (HMDA). ${ }^{130}$ These data showed that among applicants for conventional home purchase loans in 1990, blacks and Hispanics were rejected $33.9 \%$ and $21.4 \%$ of the time, respectively, as compared to a rejection rate of $14.4 \%$ for white households. ${ }^{131}$ In addition, applicants applying for loans to purchase homes in predominantly minority areas were substantially more likely to be rejected than households applying in white neighborhoods. ${ }^{132}$ Canner was careful to qualify these stark findings as not necessarily indicative of discrimination against minority borrowers or minority neighborhoods by financial institutions. ${ }^{133}$ Nevertheless, the publication of these results provoked the attention of policymakers and calls for further research to learn whether or not discrimination was indeed occurring.

In 1992, the Federal Reserve Bank of Boston released a detailed study of whether financial institutions in Boston discriminated against individual home mortgage loan applicants. ${ }^{134}$ The authors did not rely solely upon HMDA data. Instead, they supplemented it with records on individual loan applicants from mortgage originators. The study uses logit regression models to estimate the effect that being black or Hispanic or living in a black neighborhood

${ }^{130}$ Pub. L. No. 94-200, 84 Stat. 1125 (1975) (codified in scattered sections of 12 U.S.C.). Prior to 1990, lenders were required by HMDA to disclose the aggregate number and dollar value of loans originated by census tract for each of their market areas. Because these data did not disclose characteristics of individual borrowers, their usefulness in assessing financial institution lending patterns was limited. HMDA was amended in 1989 to require financial institutions to make available information about individual applicants by census tract, including their income, sex, race, the loan amount requested, and whether their applications were approved or rejected. These data formed the basis for Canner's analysis. See Canner, supra note 129, at 859.

${ }^{131}$ See Canner, supra note 129, at 868. Similar results were reported for 1991 and 1992. See Glenn B. Canner \& Delores S. Smith, Expanded HMDA Data on Residential Lending: One Year Later, 78 Fed. Res. Bull. 801, 808-09 (1992); Glenn B. Canner et al., Residential Lending to Low-Income and Minority Families: Evidence from the 1992 HMDA Data, 80 Fed. Res. Bull. 79 (1994).

192 See Canner, supra note 129, at 872-73.

${ }^{13 s}$ See id. at 880-81.

134 See Alicia H. MunNell et AL., MORTGage LENDing in Boston: INTERPRETING HMDA DATA (Federal Reserve Bank of Boston Working Paper No. 92-7, 1992). Another study by Schill and Wachter, however, found no evidence to support the hypothesis that mortgage originators in Boston or Philadelphia discriminated against loan applicants based upon the racial composition of the neighborhoods in which they sought to purchase homes. See Michael H. Schill \& Susan M. Wachter, A Tale of Two Cities: Racial and Ethnic Geographic Disparities in Home Mortgage Lending in Boston and Philadelphia, 4 J. Housing RES. 245, 272 (1993) ("Our results do not support the hypothesis that financial institutions redline neighborhoods."). 
has on the probability of being rejected for a mortgage loan in Boston. After controlling for an array of socioeconomic, locational, and credit history variables, the authors found that being black or Hispanic was significantly related to having one's loan application denied. They estimated that, on average, blacks and Hispanics were $56 \%$ more likely than whites to be rejected. ${ }^{135}$ The authors, however, failed to find a significant relationship between the racial and ethnic composition of neighborhoods and loan rejection. ${ }^{136}$

These empirical results, suggesting that racial minorities were being discriminated against by financial institutions, set off a firestorm of debate in Washington. Much of this debate focused on efforts to expand the scope and strengthen enforcement of the Community Reinvestment Act of 1977 (CRA). ${ }^{137}$ Congress enacted the CRA to eliminate the practice of redlining. Although the word "redlining" probably meant different things to different members of Congress, ${ }^{138}$ the sponsor of the legislation, Senator William Proxmire, defined it as follows:

By redlining let me make clear what I am talking about, I am talking about the fact that banks and savings and loans will take their deposits from a community and instead of reinvesting them in that community, they will invest them elsewhere, and they will

${ }^{195}$ See MUNNELL ET AL., supra note 134, at 34. The Boston Federal Reserve Bank study has been replicated by members of the Housing Research staff of the Federal National Mortgage Association. Their results substantially support the validity of the earlier study. See James H. Carr \& Isaac F. Megbolugbe, The Federal Reserve Bank of Boston Study on Mortgage Lending Revisited, 4 J. Housing REs. 277, 311 (1993) ("Our study confirms these results and refutes recent reports that attempted to discredit the original Boston Fed Research."). Other studies have been more critical of the methodology of the Boston Fed. See, e.g., Mitchell B. Rachlis \& Anthony M.J. Yezer, Serious Flaws in Statistical Tests for Discrimination in Mortgage Markets, 4 J. Housinc RES. 315, 326-30 (1993) (noting the econometric problems with studies such as the Boston Fed's); Stan Liebowitz, A Study That Deserves No Credit, WaLl ST. J., Sept. 1, 1993, at A14; Mark Zandi, Boston Fed's Bias Study Was Deeply Flawed, AM. BANKER, Aug. 19, 1993, at 13.

${ }^{136}$ See MUNNELL ET AL., supra note 134, at 59. For similar findings on the impact of neighborhood racial and ethnic characteristics on loan acceptance and rejection, see Schill \& Wachter, supra note 134, at 266-68.

${ }^{137}$ Community Reinvestment Act of 1977, Pub. L. No. 95-125, tit. VIII, 91 Stat. 1147 (codified as amended at 12 U.S.C. $\$ \S 2901-05$ (1988 \& Supp. V 1993)). In addition, the Justice Department and HUD have reached an agreement to share information regarding possible lawsuits against lenders under the Fair Housing Act. For a discussion of the Fair Housing Act, see infra text accompanying notes 167-188.

${ }^{138}$ See ROLAND E. BRANDEL \& DAVID E. TEITELbaUM, The COMMUNITY REINVESTMENT ACT: POLICIES AND COMPLIANCE I 1.01(c), at I-6 (2d ed. 1995) ("The term 'redlining' meant different things to those who used it in 1977 , referring in a variety of contexts to a variety of practices and results."). 
actually or figuratively draw a red line on a map around the areas of their city, sometimes in the inner city, sometimes in the older neighborhoods, sometimes ethnic and sometimes black, but often encompassing a great area of their neighborhood. ${ }^{139}$

\section{The CRA requires}

each appropriate Federal financial supervisory agency to use its authority when examining financial institutions, to encourage such institutions to help meet the credit needs of the local communities in which they are chartered consistent with the safe and sound operation of such institutions. ${ }^{140}$

The primary tool that these federal financial supervisory agencies have to achieve the purposes of the CRA is the power to approve or disapprove applications for bank charters, deposit insurance, branching, mergers, and the purchase of shares in other regulated financial institutions. ${ }^{141}$

The federal supervisory agencies have developed criteria upon which they judge whether a member institution has met its CRA requirements. ${ }^{142}$ Among the criteria are the following: geographic distribution of the institution's credit extensions, applications, and denials; its record of originating loans in its community; any practices that either discourage loan applications or that constitute prohibited discrimination; and financial participation in local community development programs. ${ }^{143}$ Although the federal supervisory agencies are empowered to deny merger and branching applications on the part of member institutions, until recently they have used this power very sparingly.

Nevertheless, many financial institutions have responded to the CRA by establishing elaborate community reinvestment plans and activities. Most large banks have hired full-time community reinvestment officers. In addition, many banks have inaugurated programs that seek to increase the flow of mortgage funds to inner-

139123 CONG. REC. $S 8958$ (daily ed. June 6, 1977).

${ }^{140} 12$ U.S.C. $\$ 2901$ (b) (1988 \& Supp. V 1993).

${ }^{141}$ See $\$ \S 2902-03$.

142 These criteria are currently in the process of being revised. See Community Reinvestment Act Regulations, 58 Fed. Reg. 67,466, 67,466 (1993) (to be codified at 12 C.F.R. pts. 25, 228, 345, 563e).

${ }^{143}$ Other criteria include efforts to ascertain the credit needs of an institution's community, participation of its board of directors in developing a community reinvestment strategy, marketing activities, participation in government-guaranteed or subsidized loan programs, and ability to meet the credit needs of its communities given its particular circumstances. See 12 C.F.R. \$228.7 (1988) (discussing assessment criteria for banks in Federal Reserve System). 
city communities and racial minorities. ${ }^{144}$ In addition to traditional lending, a growing number of financial institutions invest in community development corporation housing and economic development projects. ${ }^{145}$

Following publication of the 1990 HMDA data and the Boston Federal Reserve Bank study, several legislative and regulatory efforts have been made to strengthen the CRA. For example, bills have been introduced in Congress to broaden the scope of the CRA to include foreign banks, credit unions, and mortgage banks. ${ }^{146}$ In addition, at the urging of the Clinton Administration, the federal regulatory agencies charged with enforcing the CRA have published proposed regulations that set standards for judging financial institution performance. ${ }^{147}$ Indeed, over the past two years, these agencies have more vigorously enforced the CRA, rejecting the applications of several financial institutions for mergers and charter changes. ${ }^{148}$

As our discussion of the impact of the Section 235 Homeownership Program demonstrates, government programs that seek to target spatially the flow of home finance capital may have unintended negative consequences. ${ }^{149}$ On the one hand, increased levels of homeownership in the inner city may help stabilize declining neighborhoods and even promote the inmigration of marginally higher income households. On the other hand, some studies report higher than average rates of default among poor and

144 See, e.g., EdwiN S. Mills \& LUAN S. LubUele, Performance ANalysis of COMMUNITY REINVESTMENT LENDING Programs (1993) (evaluating several community lending programs); Daniel D. Pearlman \& Roger L.Q. Nguyen, The Community Reinvestment Act: 15 Years Later, 21 HousING L. Bull. 117, 121-26 (1991) (discussing CRA initiatives).

145 See Kenneth H. Thomas, Community Reinvestment Performance: Making CRA WORK FOR BANKS, COMMUNITIES AND REGULATORS 133-40 (1993) (describing community development activities of banks with "outstanding" CRA ratings).

${ }^{146}$ See, e.g., H.R. 1700, 102d Cong., 2d Sess. (1992) (proposing the Community Reinvestment Act Reform Act of 1992).

${ }^{147}$ See 59 Fed. Reg. 51,232 (1994) (to be codified at 12 C.F.R. pt. 25, pt. 563c) (proposed Oct. 7, 1994); see also Regulatory Plan for FY 1995, 59 Fed. Reg. 57,168, 57,170 (1994) (describing the issuance of revised regulations supplementing the CRA as a "major priority").

148 See, e.g., Fed Bars Acquisitions, WALl ST. J., May 19, 1993, at A6 (reporting the Federal Reserve Board's denial of a proposed acquisition of bank holding companies by First Colonial Bankshares Corporation because of its poor community lending record); Robyn Meredith, OTS Cites Poor CRA Grades in Blocking Four Charter Flips, AM. BANKER, Feb. 22, 1994, at 4 (discussing the rejection of charter changes because of low CRA ratings).

${ }^{149}$ See supra text accompanying notes 110-16. 
minority borrowers. ${ }^{150}$ To the extent that the CRA encourages financial institutions to take undue risks in accepting the loan applications of poor and minority households in predominantly poor and minority neighborhoods, and to the extent that these households ultimately default on their loans, neighborhood disinvestment could be exacerbated.

Enforcement of the CRA may also intensify the spatial concentration of poverty in America's cities. As part of their investigation to determine whether financial institutions are meeting their obligations under the CRA, federal regulators examine geographic patterns of loan origination as well as evidence of possible racially discriminatory practices. ${ }^{151}$ In addition, federal regulators look for a correspondence between deposits in a neighborhood and the amount of loans originated there. ${ }^{152}$ In order to meet their obligations under the GRA and to insulate themselves against challenges by neighborhood advocacy groups, financial institutions may be willing to make loans to marginal borrowers when they apply for loans to purchase homes in predominantly poor neighborhoods. These lending practices may create a "loan concentration effect," effectively steering poor homebuyers to poor neighborhoods. Similarly, to the extent that federal regulators examine racial patterns of acceptance and rejection, financial institutions may make it easier for racial or ethnic minorities to obtain loans in predominantly minority communities than in white neighborhoods.

To examine whether patterns of loan acceptances are consistent ${ }^{153}$ with the hypothesis that the CRA promotes loan concentration effects, we model the lender's decision to accept or reject a borrower. This decision is hypothesized to be a function of the economic determinants of risk and expected return. In any particular census tract, the probability that an applicant will be rejected can be expressed as follows:

$$
\operatorname{Prob}(P)_{i}=f\left(I_{i}, C_{j}, I_{i}^{s}, C_{j}^{s}, P_{i}^{*} C_{j}^{s}\right)
$$

${ }^{150}$ See James A. Berkovec et al., Race, Redlining, and Residential Mortgage Loan Performance, 9 J. REAL EST. FIN. \& ECON. 263, 287 (1994).

${ }^{151}$ See 12 C.F.R. § 228.7(e)-(f) (1994).

152 See THOMAs, supra note 145 , at $117,189-90$.

${ }^{153}$ Our econometric analysis can only determine whether lending patterns are consistent with loan concentration effects attributable to the CRA. Alternative hypotheses may explain why these loan concentrations are observable. See infra text accompanying notes $155-56$. 
where $P_{i}$ is the probability that a mortgage loan application by individual $i$ for a dwelling unit in census tract $j$ is rejected; $I_{i}$ and $C_{j}$ are sets of risk-related individual loan application and census tract characteristics, respectively; and $P_{i}$ and $C_{j}$ are income and area income composition variables. $P=1$ if the loan application is rejected and $P=0$ if the application is accepted. To test whether loan concentration effects occur, we include a term that interacts individual borrower and neighborhood income $\left(P_{i}^{*} C_{j}^{s}\right)$.

Table VI sets forth the independent or "control" variables in our model. With respect to individual risk-related characteristics of applicants, among other variables, we include in our model the applicant's net worth, credit history, loan-to-value ratio, debt-toincome ratio, employment status, and whether his or her household income is less than $80 \%$ of the area's median income. ${ }^{154}$ The proxies for census tract risk include variables measuring median household income, house value, proportion of housing that is owner-occupied, residential vacancy rates, and a dummy variable indicating whether the median income of households in the tract is greater than or equal to $80 \%$ of the area's median income. With respect to race- and ethnicity-related variables, we include dummy variables for whether the applicant is black or Hispanic and variables measuring the proportion of the census tract households headed by a black or Hispanic person. The dependent variable in our model is a dummy variable that takes on the value of " 1 " if the applicant is rejected for a loan and the value of " 0 " if he or she is accepted.

${ }^{154}$ The $80 \%$ cut-off corresponds to the definition of a low-income household in the Housing Act of 1937. See supra note 122 and accompanying text. 


\section{TABLE VI}

\section{MORTGAGE APPLICATION REJECTION LOGIT REGRESSION VARIABLE DEFINITIONS AND DESCRIPTIONS}

\begin{tabular}{|c|c|}
\hline $\begin{array}{l}\text { DEPENDENT } \\
\text { VARIABLE }\end{array}$ & DESCRIPTION \\
\hline
\end{tabular}

\begin{tabular}{ll}
\hline REJECT & $\begin{array}{l}\text { Dummy variable with value of " } 1 \text { " if applicant was } \\
\text { rejected for a loan and " } 0 \text { " if he she was accepted }\end{array}$
\end{tabular}

INDEPENDENT

VARIABLE

DESCRIPTION

REXPINC

ROBLINC

NW

CHISTORY

MHISTORY

PHISTORY

PUNEMPL

SELF

LARATIO

MULFAM

BLACK

HISP

MEDHHINC

MEDVALUE

MEDAGSTR

ROWN

RVACUNIT

RWELFARE
Dummy variable with value of " 1 " if ratio of housing expense to income is greater than 0.3 and " 0 " if not

Ratio of total debt to household income

Net Worth (in \$1000s)

Scaled values (1-5) of consumer credit history with " 5 " representing highest risk

Scaled values (0-3) of mortgage payment credit history with " 3 " representing highest risk

Scaled values (0-5) of public record credit history with " 5 " representing highest risk

Probability of unemployment in applicant's industry

Dummy variable with value of " 1 " if applicant is selfemployed and " 0 " if not

Ratio of loan amount requested to appraised value of property

Dummy variable with value of " 1 " if unit is in multifamily building and " 0 " if not

Dummy variable with value of " 1 " if applicant is black and " 0 " if not

Dummy variable with value of " 1 " if applicant is Hispanic and " 0 " if not

Median household income in census tract

Median value of owner-occupied units in census tract

Median age of structures in census tract

Proportion of households in census tract that are owner-occupants

Proportion of units in census tract that are vacant

Proportion of households receiving public assistance in census tract 
HHRBLACK

HHRSPAN

GHISTORY

NREVIEW

UNVINF

LOMODIND

NLOWAREA

INTERACT
Proportion of households headed by a black person in census tract

Proportion of households headed by an Hispanic person in census tract

Dummy variable with value of " 1 " if applicant's credit history meets financial institution's loan guidelines and " 0 " if not

Number of times loan application was reviewed by underwriter

Dummy variable with value of " 1 " if application contains unverifiable information and " 0 " if it does not

Dummy variable with value of " 1 " if applicant's household income is less than $80 \%$ of the metropolitan median income and " 0 " if higher

Dummy variable with value of " 1 " if applicant is seeking a loan in a census tract with a median household income greater to or equal to $80 \%$ of the metropolitan median household income and " 0 " if not

Dummy variable with a value of " 1 " if applicant is a LOMODIND seeking a loan in a NLOWAREA and " 0 " if not 
If loan concentration effects occur, we would expect that the variable (INTERACT), measuring the interaction of being a lowincome individual (LOWMODIND) applying for a loan in an area that is not composed of low-income households (NLOWAREA) to have a positive sign and be statistically significant. In other words, if loan concentration effects occur, low-income applicants applying in nonpoor areas should have a greater chance of being rejected than low-income people applying in low-income neighborhoods.

Importantly, although a positive and statistically significant value for the INTERACT variable would be consistent with the hypothesis that the CRA causes poor people to have more success when applying for loans in poor areas than in nonpoor areas, it would not necessarily prove that the legislation is having this effect. Instead, loan concentration effects may occur for reasons unrelated to the CRA. For example, as a result of informational economies, neighborhood banks may have better information on nearby areas than other financial institutions. ${ }^{155}$ Another possible explanation for loan concentration effects would be discriminatory racial steering practices, especially in metropolitan areas where race is highly correlated with income. ${ }^{156}$

To test our hypothesis of loan concentration effects, we use a subset of the data collected by the Boston Federal Reserve Bank in 1990 from financial institutions in the Boston metropolitan area. Each applicant's record was matched with data from the 1990 Census of Population and Housing to obtain characteristics of the census tract in which he or she was seeking to purchase a house. ${ }^{157}$ The model was then estimated using a logit regression. The results are set forth in Table VII.

${ }^{155}$ Cf. LEONARd I. NAKAMURA, LOAN SCREENING WITHIN AND OUTSIDE OF CUSTOMER RELATIONSHIPS (Federal Reserve Bank of Phila. Working Paper No. 93-15, 1993); Leonard I. Nakamura, Information Externalities: Why Lending May Sometimes Need a Jump Start, FED. ReSERVE BANK OF PHILA. BUS. REV., Jan.-Feb. 1993, at 3, 3.

${ }^{136}$ For a more detailed explanation of alternative explanations for an empirical finding of loan concentration effects, see Michael H. Schill \& Susan M. Wachter, Borrower and Neighborhood Racial and Income Characteristics and Financial Institution Mortgage Application Screening, 9 J. REAL EST. FIN. \& ECON. 223 (1994).

${ }^{157}$ Because of confidentiality restrictions, the Federal Reserve Bank of Boston has not released its entire data set. Therefore, our study is based upon a subset of the Boston Federal Reserve Bank's data set and is augmented by HMDA data released in 1990. This subset does not indicate census tract information for individual applicants. To determine census tracts, we matched Boston Federal Reserve Bank information to HMDA applicant data which do provide census tract identifiers. For observations for which this match could not be made ( 347 observations out of a total of 3061 ), we used mean census tract values. 
TABLE VII

MORTGAGe APPLICATION REJECTION REgRESSION RESUlTS (DEPENDENT VARIABLE-PROBABILITY OF REJECTION)

\begin{tabular}{|c|c|c|}
\hline VARIABLE & COEFFICIENT & STANDARD ERROR \\
\hline INTERCEPT & -0.883 & 1.004 \\
\hline REXPINC & 0.269 & 0.203 \\
\hline ROBLINC & $0.053^{* * *}$ & 0.010 \\
\hline NW & $6 \times e^{-5}$ & $1 \times e^{-4}$ \\
\hline CHISTORY & -0.027 & 0.057 \\
\hline MHISTORY & 0.122 & 0.154 \\
\hline PHISTORY & $0.629^{* *}$ & 0.249 \\
\hline PUNEMPL & $0.074^{* *}$ & 0.035 \\
\hline SELF & $0.613^{* * *}$ & 0.238 \\
\hline LARATIO & $1.553^{* *}$ & 0.627 \\
\hline MULFAM & $0.815^{\circ * *}$ & 0.229 \\
\hline BLACK & 0.114 & 0.236 \\
\hline HISP & 0.175 & 0.305 \\
\hline MEDHHINC & $-1 \times e^{-5}$ & $2 \times e^{-5}$ \\
\hline MEDVALUE & $3 \times e^{-6}$ & $2 \times e^{-6}$ \\
\hline MEDAGSTR & $-0.023^{* *}$ & 0.009 \\
\hline ROWN & -0.006 & 0.009 \\
\hline RVACUNIT & -0.015 & 0.022 \\
\hline RWELFARE & $0.059^{\circ *}$ & 0.030 \\
\hline HHRBLACK & 0.010 & 0.006 \\
\hline HHRSPAN & $0.038^{*}$ & 0.023 \\
\hline GHISTORY & $-3.512^{* * *}$ & 0.259 \\
\hline NREVIEW & $-0.295^{\circ \cdots \bullet}$ & 0.077 \\
\hline UNVINE & $3.216^{*: *}$ & 0.270 \\
\hline LOMODIND & $-0.946^{* * *}$ & 0.337 \\
\hline NLOWAREA & $-0.485^{*}$ & 0.281 \\
\hline INTERACT & $1.591^{* \cdots}$ & 0.413 \\
\hline
\end{tabular}

- Significant at $10 \%$ level

* Significant at $5 \%$ level

-.. Significant at $1 \%$ level 
Most of the variables in our model have the expected signs and many are statistically significant. For example, higher probabilities of unemployment (PUNEMPL), larger loan-to-value ratios (LARATIO), and blemished credit records (PHISTORY) are all positively related to being rejected for a mortgage loan. Homebuyers in areas with higher proportions of residents receiving public assistance (RWELFARE) are more likely to be rejected, whereas those applying in areas that are not predominantly low-income neighborhoods (NLOWAREA) are less likely to have their applications turned down.

As our hypothesis predicts, however, once the income of the loan applicant is interacted with the income of the neighborhood in which he or she seeks to purchase a home, a different result emerges. Instead of being less likely to be rejected when they apply for loans in nonpoor neighborhoods, low-income applicants face a higher probability of rejection. This result would be unsurprising had we not controlled for borrower, loan, and neighborhood characteristics. Our model, however, did control for these risk factors. With all of these characteristics held constant, low-income people have a higher probability of being accepted for mortgage loans in poor neighborhoods than elsewhere. ${ }^{158}$ Moreover, nonpoor households who are otherwise similar to poor households have a higher probability of being rejected in low-income neighborhoods.

Indeed, the magnitude of this loan concentration effect is substantial. In Table VIII, we use the results of our logit regression to predict the rejection rates of poor and nonpoor persons who are applying for loans in poor and nonpoor neighborhoods. We find that an average low-income person applying for a loan in a predominantly nonpoor neighborhood is almost three times more likely to be rejected than if he or she had applied in a neighborhood predominantly composed of poor residents. Although these results do not prove that the CRA creates incentives that cause the concentration of low-income homebuyers in low-income neighborhoods, ${ }^{159}$ they are consistent with that hypothesis. ${ }^{160}$

${ }^{159}$ We also find that when the race of the individual applicant is interacted with the race of the neighborhood in which she is seeking to purchase a home, similar loan concentration effects occur. See infra note 161 and accompanying text.

${ }^{159}$ See supra text accompanying notes $155-56$ for a description of alternative hypotheses that might also explain our empirical result.

${ }^{160}$ The existence of loan concentration effects may not necessarily be harmful to individual neighborhoods. To the extent that increased levels of homeownership 


\section{TABLE VIII}

MORTGAGE APPLICATION REJECTION RATE SIMULATION

\begin{tabular}{|l||c|c||}
\cline { 2 - 3 } \multicolumn{1}{c|}{} & $\begin{array}{c}\text { CENSUS TRACT MEDIAN } \\
\text { HOUSEHOLD INCOME } \\
\text { 80\% OF METRO. MEDIAN } \\
\text { (LOWAREA) }\end{array}$ & $\begin{array}{c}\text { CENSUS TRACT MEDIAN } \\
\text { HOUSEHOLD INCOME > } \\
80 \% \text { OF METRO. MEDIAN } \\
\text { (NLOWAREA) }\end{array}$ \\
\hline $\begin{array}{l}\text { Applicant Income } \\
\text { < } 80 \% \text { of Metro. } \\
\text { Median Income }\end{array}$ & $4.25 \%$ & $11.82 \%$ \\
\hline $\begin{array}{l}\text { Applicant Income } \\
>80 \% \text { of Metro. } \\
\text { Median Income }\end{array}$ & $10.26 \%$ & $6.58 \%$ \\
\hline
\end{tabular}

In an earlier study, we also found evidence of racial concentration effects. ${ }^{161}$ Instead of interacting the income of individuals with the income of individual census tracts, we interacted the race of loan applicants with the racial composition of the neighborhoods in which they were seeking to purchase homes. We found that black applicants were more likely than white applicants to be accepted in predominantly black neighborhoods.

\section{Deconcentrating THE INNER-Gity POOR ${ }^{162}$}

Federal housing laws and policies, past and present, have contributed to the spatial segregation of poor people and racial and ethnic minorities in America's cities. Just as federal law has helped create the problem, federal law could also help to provide the solution. Policymakers have the tools at their disposal to reverse these patterns and promote economic and racial integration. This Part discusses how stepping up enforcement of antidiscrimination laws, enhancing the supply of affordable housing in economically integrated communities, and altering the public housing program could facilitate the deconcentration of poverty in urban America.

stabilize inner-city communities, encouraging low-income homebuyers to remain in their neighborhoods may improve these communities.

${ }^{161}$ See Schill \& Wachter, supra note 156, at 235.

${ }^{162}$ Part IV is not coauthored. It reflects the views of Professor Schill, but not necessarily those of Professor Wachter. 


\section{A. Antidiscrimination Law}

The Boston Federal Reserve Bank study of home mortgage lending patterns, together with recent disclosures of data pursuant to HMDA have focused the public's attention on racial discrimination in the home loan mortgage market. Studies indicate, however, that racial discrimination continues to pervade the housing market. In 1989, for example, the Urban Institute undertook a large study of discrimination in twenty-five metropolitan areas and found that $53 \%$ of black renters and $59 \%$ of black home purchasers could be expected to encounter at least one incident of racially motivated discrimination. ${ }^{163}$ Among Hispanics, the expected incidence of discrimination was $46 \%$ and $56 \%$ for renters and homebuyers, respectively. ${ }^{164}$

In most large American cities, discrimination in the housing market contributes to the segregation of minority households in inner-city neighborhoods. ${ }^{165}$ Because race is often correlated with income, racial discrimination and segregation frequently translate into high concentrations of very poor people in America's inner cities. ${ }^{166}$

I6s See MARGERY A. TURNER ET AL., HOUSING DISCRIMINATION STUDY: SYNTHESIS at vi-vii (1991). The methodology used by the Urban Institute to detect discrimination is called the fair housing audit. To conduct the audit, sales or rental advertisements are randomly selected from newspapers. Pairs of testers, one minority and one majority, are then sent separately to real estate agents' offices where they pose as potential purchasers or renters. Pairs of testers are matched on most characteristics other than race so that discrimination may be inferred from differential treatment. See id. at i-ii.

${ }^{164}$ See id. at vi-vii; $c f$. Susan M. Wachter \& Isaac F. Megbolugbe, Racial and Ethnic Disparities in Homeownership, 3 HOUSING POL'Y DEBATE 333, 359 (1992) (finding wide disparities in homeownership rates between Hispanic and non-Hispanic households).

165 The most commonly used measure of segregation is the index of dissimilarity. This index represents the proportion of a metropolitan area's population that would have to move to achieve an even distribution of minority groups throughout the metropolitan area. A high index of dissimilarity is generally thought to be 60 . See MASSEY \& DENTON, supra note 14, at 221. One recent study of the 30 metropolitan areas in the United States with the largest black populations reveals that in northern areas the average index value is 77.8 and in southern areas the average value is 66.5 . See id. at 222. Some metropolitan areas, particularly those in the Northeast and Midwest, have staggeringly high levels of segregation. Chicago (85.8) and Newark (82.5) are demonstrative. See id. (listing figures from a 1990 study). For a discussion of the causes of race segregation, see Michael H. Schill \& Susan M. Wachter, Housing Market Constraints and Spatial Stratification by Income and Race, 6 HOUSING POL'Y DEBATE 141 (1995).

166 The extent to which income differences between whites and blacks contribute to racial, as opposed to income, segregation is a matter of some debate. Several studies suggest that income differences explain only a small proportion of racial 
High levels of race discrimination and segregation in American cities are at least partially attributable to a lack of enforcement of federal antidiscrimination laws. Discrimination by race in the housing market is outlawed by a number of federal laws. Public landlords such as PHAs are forbidden to discriminate by the Equal Protection Clause of the Fourteenth Amendment. ${ }^{167}$ Discrimination in the private market is similarly made illegal by Title VIII of the Civil Rights Act of 1968, commonly referred to as the Fair Housing Act. ${ }^{168}$ The Fair Housing Act not only prohibits discrimination by most home sellers and landlords, ${ }^{169}$ but also extends to real estate agents ${ }^{170}$ and home mortgage loan originators. ${ }^{171}$

segregation. See, e.g., Karl E. TAEuber \& Alma F. TAEuber, Negroes in Cities: RESIDENTIAL SEGREGATION AND NEIGHBORHOOD CHANGE 84-85 (1965) (finding that only about one-third of race segregation is explained by income differences between whites and blacks); John F. Kain, Housing Market Discrimination and Black Suburbanization in the 1980s, in DIVIDED NEIGHBORHOODS: CHANGING PATTERNS OF RACIAL SEGREgation 68, 71-77 (Gary A. Tobin ed., 1987) (examining data from Chicago and finding that socioeconomic differences only partially explain residence patterns of blacks). But cf. George C. Galster \& W. Mark Keeney, Race, Residence, Discrimination, and Economic Opportunity: Modeling the Nexus of Urban Racial Phenomena, 24 URB. AFF. Q. 87, 105 (1988) (finding that the variable that captures the interaction of housing-price segmentation and interracial economic disparities is the "most potent exogenous component of segregation and discrimination").

${ }^{167}$ See U.S. CONST. amend. XIV.

${ }^{168} 42$ U.S.C. $\$ \S 3601-3619,3631$ (1988 \& Supp. V 1993) (prohibiting discrimination in the sale or rental of housing). Additional laws prohibiting discrimination are $\S 1982$ of the Civil Rights Act of 1866, 42 U.S.C. $\$ 1982$ (1988) (stating that “[a]11 citizens of the United States shall have the same right, in every State and Territory, as is enjoyed by white citizens thereof to inherit, purchase, lease, sell, hold, and convey real and personal property"), and the Equal Credit Opportunity Act, 15 U.S.C. $\$ 1691$ (1988 \& Supp. V 1993) (prohibiting discrimination in credit transactions).

${ }^{169}$ See 42 U.S.C. \$ 3604(a) (making it illegal to refuse to sell or rent "to any person because of race, color, religion, sex, familial status, or national origin"). Sales of single-family homes by persons who own three or fewer houses are exempt from the Fair Housing Act if the seller does not use the services of a real estate broker and does not advertise. See $\S 3603(\mathrm{~b})(1)$. Similarly, landlords who live in and own buildings occupied by no more than four families are also exempt from the prohibitions of the Fair Housing Act. See § 3603(b)(2).

${ }^{170}$ See $\S \S 3605(\mathrm{~b})(2)-3606$; see also Gladstone, Realtors v. Village of Bellwood, 441 U.S. 91, 115 (1979) (holding that the plaintiffs had standing to challenge alleged discriminatory acts of real estate agents); Chicago v. Matchmaker Real Estate Sales Ctr., Inc., 982 F.2d 1086, 1096 (7th Cir. 1992) (finding a real estate agency liable for racial steering), cert. denied, 113 S. Ct. 2961 (1994); Heights Community Congress v. Hilltop Realty, Inc., 774 F.2d 135, 141 (6th Cir. 1985) (same), cert. denied, 475 U.S. 1019 (1986).

${ }^{171}$ See $\$$ 3605(b)(1); see also Steptoe v. Savings of Am., 800 F. Supp. 1542, 1547 (N.D. Ohio 1992) (holding that a lender's discriminatory appraisal policies violate the Fair Housing Act); Watson v. Pathway Fỉn., 702 F. Supp. 186, 189 (N.D. Ill. 1988) (holding that the approval of applications of white borrowers with late payment 
It is likely that the persistence of high levels of race discrimination in the housing market, a quarter century after the passage of the Fair Housing Act, is at least partially attributable to weak enforcement of the law. ${ }^{172}$ In a legislative compromise to gain passage of the Act, its sponsors agreed to eliminate from the bill HUD's authority to hold hearings and issue complaints and cease and desist orders. ${ }^{173}$ In addition, punitive damages for violating the Act were limited to $\$ 1000.174$

In 1988, Congress significantly strengthened federal enforcement powers under the Fair Housing Act. The Fair Housing Act Amendments of $1988^{175}$ empower HUD to initiate investigations of possible violations without receiving a formal complaint. ${ }^{176}$ In addition, when it receives private complaints, HUD must investigate and issue a determination as to whether cause exists to believe that a violation of the Act has occurred. ${ }^{177}$ If such a cause determination is issued, the complainant may elect to have the matter resolved before an administrative law judge or litigated in federal court. ${ }^{178}$ If the case is litigated in federal court, the Department of Justice must prosecute the matter. ${ }^{179}$ The Act also provides for the discretionary payment of attorney's fees to prevailing parties ${ }^{180}$ and punitive damages. ${ }^{181}$

Federal enforcement efforts under the Fair Housing Act and the Fair Housing Act Amendments have been criticized by many commentators. Massey and Denton present data indicating that during the 1970 s only $10 \%$ of the cases that HUD could not resolve through conciliation were referred to the Justice Department for possible prosecution. ${ }^{182}$ During the 1980 s, according to Charles

histories creates factual issues for a determination of possible racial discrimination). ${ }^{172}$ See MASSEY \& DENTON, supra note 14, at 195-200 (describing how Congress granted only limited enforcement authority, which in turn was poorly funded and badly organized).

${ }^{173}$ See id. at 193. HUD's powers were limited to investigation and conciliation of private complaints. HUD could also refer cases involving a "pattern or practice" of discrimination to the Justice Department for possible prosecution. Id. at 196.

${ }^{174}$ See $i d$. at 198.

175 Pub. L. No. 100-430, 102 Stat. 1623 (1988) (codified at 42 U.S.C. $§ \S 3601-3608$, 3610-3619, 3631 (1988 \& Supp. V 1993)).

${ }^{176}$ See 42 U.S.C. $\$ 3610(\mathrm{a})(1)(\mathrm{A})(\mathrm{iii})$ (1988).

${ }^{177}$ See $\$ 3610$ (g).

${ }^{178}$ See $\$ 3612$ (a)-(b).

${ }^{179}$ See $\S 3612(\mathrm{o})(1)$.

${ }^{180}$ See $\S 3612(\mathrm{p})$ (administrative proceedings); $\S 3613(\mathrm{c})(2)$ (civil actions).

${ }^{181}$ See $\$ 3613(c)(1)$ (civil actions only).

182 See MASSEY \& DENTON, supra note 14, at 197. 
Lamb, the number of cases filed by the Justice Department declined from an average of thirty-two per year to only ten. ${ }^{183}$ More recently, a 1994 report by the United States Commission on Civil Rights criticized HUD and the Justice Department for insufficient resources allocated to Fair Housing enforcement, substantial backlogs and lengthy delays in processing cases, and relatively few Secretaryinitiated investigations of discriminatory practices. ${ }^{184}$

Recent executive orders by President Clinton have suggested that HUD, the Department of Justice, and the federal financial regulatory agencies will increase their efforts to fight discrimination among all participants in the housing market. The President has ordered HUD to "issue regulations to define discriminatory practices" and instructed both HUD and the Attorney General "to aggressively enforce the laws prohibiting these practices." 185 HUD has also agreed to streamline its complaint process, expand investigation of the lending practices of mortgage companies, inaugurate a testing program for mortgage originators in areas with high minority rejection rates, and create at least a dozen fair housing enforcement organizations in underserved areas of the

${ }^{183}$ See Charles M. Lamb, Fair Housing Implementation from Nixon to Reagan 6-7 (Aug. 29, 1991) (unpublished paper, on file with authors). A further criticism voiced by some commentators is the refusal by the Justice Department during the 1980 s to prosecute fair housing cases using the disparate impact test. Because of the difficulty of proving intent, most federal courts permit plaintiffs to bring an action under the Fair Housing Act on the ground that a seemingly benign practice by an owner, real estate agent, or landlord has a discriminatory effect on a protected group. See, e.g., Huntington Branch, NAACP v. Town of Huntington, 844 F.2d 926, 941-42 (2d Cir.) (holding that the town violated the Fair Housing Act by refusing to amend an ordinance that restricted private, multifamily housing projects to predominantly minority urban renewal areas), aff d, 488 U.S. 15 (1988); Metropolitan Hous. Dev. Corp. v. Village of Arlington Heights, 558 F.2d 1283, 1285 (7th Cir. 1977) (holding that, under the Fair Housing Act, the village was obligated to avoid zoning policies that prevented the construction of low-cost housing within its boundaries), cert. denied, 434 U.S. 1025 (1978); United States v. City of Black Jack, 508 F.2d 1179, 1183-84 (8th Cir. 1974) (applying the Fair Housing Act to local government), cert. denied, 422 U.S. 1042 (1975). Once the plaintiff meets its burden of proving discriminatory effect, the burden then shifts to the defendant to show that the practice is justified by business necessity. If the defendant fails to meet this burden, the plaintiff succeeds in proving discrimination. Despite nearly unanimous judicial approval of the disparate impact test by federal courts, the Reagan and Bush Justice Departments took the position that discriminatory intent must be shown to prove violations of the Fair Housing Act. See U.S. COMM'N ON CIVIL RIGHTS, THE FAIR HOUSING AMENDMENTS ACT OF 1988: THE ENFORCEMENT REPORT 196 (1994).

${ }^{184}$ See U.S. COMM'N ON CIVIL RIGHTS, supra note 183, at 221-22, 229.

${ }^{185}$ Memorandum for the Heads of Executive Departments and Agencies, 59 Fed. Reg. 8513, 8515 (1994). 
country. ${ }^{186}$ In addition, the federal financial agencies charged with examining the compliance of most financial institutions with federal laws have issued regulations defining violations of federal antidiscrimination laws ${ }^{187}$ and have committed themselves to increased examination of patterns of loan acceptance and rejection and to referral of possible violations to the Justice Department. ${ }^{188}$

Social scientists, through the fair housing audit methodology, have demonstrated beyond any doubt the existence of systemic racial discrimination among home sellers and real estate agents in the United States. ${ }^{189}$ Although the Boston Federal Reserve study and some anecdotal reports and lawsuits suggest that race discrimination may also exist among home loan mortgage originators, the evidence to date is not conclusive. ${ }^{190}$ Additional research needs to be undertaken to learn whether lending discrimination is similarly widespread. To the extent that discrimination is found to exist among participants in the housing market, increased enforcement of the Fair Housing Act would be a useful tool to enable poor, minority inner-city residents to attain housing outside of inner-city neighborhoods.

\section{B. Enhanced Housing Affordability in Economically Integrated Areas}

Vigorous enforcement of antidiscrimination laws will do little to deconcentrate the inner-city poor if a sufficient supply of affordable housing does not exist outside of the inner city. In many metropolitan areas, particularly in the suburbs, local governments enact land use regulations, such as zoning ordinances, impact fees, and growth controls, that have the effect of limiting the supply of low-cost housing and inflating prices. These ordinances may be motivated

186 See Annex to Performance Agreement Between the President of the United States, William Jefferson Clinton, and the Secretary of Housing and Urban Development, Henry G. Cisneros I 4 (Mar. 18, 1994) (on file with authors).

${ }^{187}$ See Policy Statement in Discrimination in Lending, 59 Fed. Reg. 18,266 (1994).

${ }^{183}$ See Statement by Lawrence B. Lindsey, Member, Board of Governors of the Federal Reserve System, Before the Senate Committee on Banking, Housing, and Urban Affairs (Nov. 4, 1993) (on file with authors). HUD and the Department of Justice have also committed themselves to using the disparate impact test in prosecuting cases of housing discrimination. See HUD v. Mountain Side Mobile Estates Partnership, 1993 WL 307069, at *5 (H.U.D. July 19, 1993) (stating that the disparate impact test should be used to determine whether the Act has been violated); U.S. COMM'N ON CIVIL RIGHTS, supra note 183, at 196.

${ }^{189}$ See supra notes 163-64 and accompanying text.

${ }^{190}$ See supra notes 134-36 and accompanying text. 
by the desire to preserve environmental amenities, avoid overcrowding of public facilities, maintain socially and racially homogenous communities, preserve property values, and avoid cross-subsidization of lower income households. ${ }^{191}$

Regardless of the motivation behind these local regulations, empirical studies have demonstrated that they typically increase the cost of housing. ${ }^{192}$ Indeed, in some instances, communities absolutely prohibit all types of housing that might be affordable to low- and moderate-income households. If a substantial proportion of the inner-city poor are to be enabled to move away from their current neighborhoods, land-use barriers must be lowered so as to permit the construction of low-cost housing. ${ }^{193}$ The federal government has, for the most part, avoided involving itself in issues of local land use regulation. ${ }^{194}$ Nevertheless, this reticence does not necessarily mean that no federal role exists. Indeed, in 1991 a federal commission, appointed by President Bush, recommended that Congress reward states and localities that reduced regulatory barriers and withhold federal housing and community development funds from those that did not. ${ }^{195}$ The bulk of the Commission's

${ }^{191}$ Individuals can avoid cross-subsidizing others by forming homogenous communities. See Charles M. Tiebout, A Pure Theory of Local Expenditures, 64 J. POL. ECON. 416, 420-21 (1956). Zoning regulations can be used to set a minimum value on property in a community to ensure that no one who lives in the jurisdiction pays less in property taxes than her proportionate share of the cost of services provided, thus avoiding cross-subsidization. See Bruce W. Hamilton, Zoning and Property Taxation in a System of Local Governments, 12 URB. STUD. 205, 207 (1975) (creating a theoretical model for the use of zoning and property tax).

192 The fact that land use regulations increase the cost of housing does not necessarily imply that they are inefficient. For a summary of the literature discussing the efficiency of land use regulations and demonstrating the effect of land use regulations on housing prices, see WILLIAM A. FISCHEL, DO GROWTH CONTROLS MATTER? A REVIEW OF EMPIRICAL EVIDENCE ON THE EFFECTIVENESS AND EFFICIENCY of Local Government Land Use Regulation (1990); Henry O. Pollakowski \& Susan M. Wachter, The Effects of Land-Use Constraints on Housing Prices, 66 LAND ECON. 315 (1990); Schill \& Wachter, supra note 165.

${ }^{193}$ Professor Roisman notes that Fair Housing enforcement combined with shallow subsidies in the suburbs may actually increase concentrated inner-city poverty because only moderate-income families would be able to take advantage of them. See Roisman, supra note 62 , at 1374 . Section 8 subsidies that subsidize individuals, however, can be targeted to the very poorest households in a community and thus avoid this "creaming" effect.

${ }^{194}$ For brief histories of federal efforts to reduce exclusionary zoning practices in the suburbs, see MichaEL N. DANIELSON, THE POLITICS OF EXCLuSION 213-42 (1976); Michael H. Schill, The Federal Role in Reducing Regulatory Barriers to Affordable Housing in the Suburbs, 8 J.L. \& POL. 703, 722-29 (1992).

195 See ADVISORY COMM'N ON REgULATORY BARRIERS TO AFFORDABLE HOUS., "NOT 
proposals, however, were never voted on by Congress.

Easing local regulations that increase the cost of new housing in the suburbs would create an incentive for developers to construct affordable housing. Even with relaxed land-use barriers, however, most households currently living in neighborhoods of concentrated inner-city poverty would probably still require government rental assistance to afford the housing that would be constructed. At present, the federal government provides two types of subsidies to households renting in buildings owned by private landlords. The Section 8 Existing Housing Certificate Program provides tenants whose homes cost no more than the federally prescribed Fair Market Rent (FMR) with a subsidy equal to the difference between $30 \%$ of their incomes and their rents. ${ }^{196}$ The Section 8 Housing Voucher Program operates somewhat differently. Instead of a subsidy based upon actual rent, voucher recipients receive the difference between $30 \%$ of their incomes and a hypothetical rent based on the applicable FMR for their area. ${ }^{197}$

The two Section 8 demand-oriented assistance programs avoid many of the problems that plague supply-oriented housing subsidies such as public housing. ${ }^{198}$ In theory, tenants can find housing in neighborhoods that they prefer, rather than being forced into neighborhoods of concentrated poverty. In practice, however, demand-oriented subsidies have never realized their potential for achieving the deconcentration of poor households. Empirical studies of housing allowances and vouchers indicate that many households remain in their current neighborhoods rather than move elsewhere. ${ }^{199}$ The average increase in neighborhood median income for those households that do move tends to be modest. ${ }^{200}$

IN MY BACK YARD": REMOVING BARRIERS TO AFFORdABle HousING 3-6 (1991).

${ }^{196}$ See 42 U.S.C. $\$ 1437 f(c)$ (1988 \& Supp. V 1993).

${ }^{197}$ See 42 U.S.C. $\$ 1437 f(0)$ (1988 \& Supp. V 1993). Tenants under both Section 8 programs must find housing that meets minimum federal quality standards. See 24 C.F.R. $§ 882$ (1994).

${ }^{198}$ Housing vouchers and certificates are categorized as "demand-oriented" subsidies because they directly stimulate demand, as opposed to "supply-oriented" programs such as public housing, which subsidize producers of housing. For a comparison of the effectiveness of demand- and supply-oriented subsidies in achieving the objectives of housing policy, see Schill, supra note 28 , at 526-40.

${ }^{199}$ See Frieden, supra note 104, at 184 (stating that for blacks, "[e]ven many of those who can afford to move to new housing in suburbia are blocked by discrimination or hostility and are forced to stay in central city ghettos"); Jennifer L. Stucker, Race and Residential Mobility: The Effects of Housing Assistance Programs on Household Behavior, in Housing Desegregation AND FEdERAL POLIGY 253, 254 (John M. Goering ed., 1986).

${ }^{200}$ See Mireille L. Leger \& Stephen D. Kennedy, U.S. DeP'T OF Hous. AND 
In addition, a relatively small proportion of recipients is unable to locate suitable housing and must return their vouchers. ${ }^{201}$

Increased enforcement of the Fair Housing Act and relaxed regulatory barriers to affordable housing in the suburbs would facilitate the ability of households to utilize housing vouchers and certificates to leave neighborhoods of concentrated poverty. In addition, changes in the Section 8 program itself might enhance its effectiveness in achieving deconcentration. These changes would improve the ability of Section 8 recipients to utilize vouchers throughout their metropolitan areas.

In most instances, Section 8 tenant assistance programs are administered by PHAs, which are typically geographically coterminous with municipalities. Therefore, within a metropolitan area, dozens of PHAs may operate separate rent subsidy programs. In 1987, Congress passed legislation permitting Section 8 certificate and voucher holders to utilize their rent subsidies outside the jurisdiction that issued them. ${ }^{202}$ In 1992 , however, at the urging of PHAs, Congress restricted the portability of Section 8 subsidies by requiring recipients who did not already live in the jurisdiction of an issuing PHA to remain within that jurisdiction for at least twelve months. ${ }^{203}$ The utility of Section 8 in promoting the

URbaN DEV., Recipient HOUSING IN THE HOUSING VOUCHER AND CERTIFICATE PROGRAMS 5 (1990) ("The average per capita income in tracts occupied by recipients who moved was 4 percent higher than that in the tracts in which they had previously lived."); Bernard J. Frieden, Housing Allowances: An Experiment That Worked, in Federal housing Policy and Programs: Past and Present 365, 375 (J. Paul Mitchell ed., 1985) (finding a small tendency for households to move to somewhat higher-income neighborhoods in the Experimental Housing Allowance Program (EHAP)); John C. Weicher, The Voucher/Production Debate, in BUILDING FOUNDATIONS: Housing AND FEDERAL POLICY 263, 282 (Denise DiPasquale \& Langley C. Keyes eds., 1990) (finding that for those participants in EHAP who moved, the increase in neighborhood income was small).

${ }^{201}$ See StePhen D. KenNedy, Section 8 Rental Voucher and Rental CertifiCATE UTILIZATION STUDY at ii (1994) (finding that 87\% of the national sample of voucher and certificate recipients successfully obtained housing); Meryl Finkel \&c Stephen D. Kennedy, Racial/Ethnic Differences in Utilization of Section 8 Existing Rental Vouchers and Certificates, 3 HOUSING POL'Y DEBATE 463, 478 (1992) (listing an overall success rate of $73 \%$ in 18 jurisdictions, excluding New York City); Weicher, supra note 200 , at 274 (reporting that 75\% of the households in EHAP that expressed interest were able to locate suitable housing).

${ }^{202}$ See Housing and Community Development Act of 1987, Pub. L. No. 100-242, $\S 145,101$ Stat. 1815,1852 (1988) (codified at 42 U.S.C. $\$ 1437 f(r)(1988)$ ).

${ }^{203}$ See Housing and Community Development Act of 1992, Pub. L. No. 102-550, \$ 147, 106 Stat. 3672, 3715 (codified at 42 U.S.C. $\$ 1437 f(r)(1)$ (Supp. V 1993)). PHAs supported this amendment because of concerns that households would shop among jurisdictions for the shortest waiting list. 
movement of poor households from inner cities to suburbs is also limited by the ability of municipalities to grant preferences to their own residents in obtaining assistance. ${ }^{204}$

Congress could facilitate the mobility of households among jurisdictions within a metropolitan area by eliminating all barriers to Section 8 portability. ${ }^{205}$ One alternative would be to consolidate the administration of the Section 8 program at the metropolitan level. Alternatively, all households receiving Section 8 assistance could be permitted to use to their vouchers and certificates to locate housing regardless of whether the housing is located within the borders of the PHA that provided the assistance.

Although consolidating administration of the Section 8 program at the metropolitan level might enhance mobility, current methods of computing FMRs based upon median metropolitan rents inhibit the ability of certificate and voucher holders to move to more economically integrated surroundings. At present, FMRs are set at the fortieth percentile of rents in a metropolitan area. In many metropolitan areas, however, rents are much higher in the suburbs than in central cities. ${ }^{206}$ Basing FMRs on average metropolitan rents ignores this diversity and geographically circumscribes the areas in which Section 8 recipients can live. Altering the computation method for FMRs to decentralized geographic units such as counties or PHAs would increase housing options for low-income households in economically integrated communities. ${ }^{207}$

${ }^{204}$ See, e.g., Fayerweather v. Town of Narragansett Hous. Auth., 848 F. Supp. 19, 22 (D.R.I. 1994) (holding that preference to residents for Section 8 assistance does not violate the right to interstate travel).

${ }^{205}$ Restrictions on portability, however, might be justified if Section 8 subsidies were to be used as a neighborhood redevelopment tool. In these instances, targeting Section 8 to particular neighborhoods might, in combination with other initiatives to renovate housing, ameliorate the public goods problem of uncoordinated investment. For a discussion of the economic justification for housing assistance as opposed to pure income redistribution, see Michael H. Schill, Privatizing Federal Low Income Housing Assistance: The Case of Public Housing, 75 CORNELl L. REV. 878, 890-93 (1990).

${ }^{206}$ See U.S. Gen. Accounting Office, Rental Housing: Use of Smaller Market AReas to Set Rent Subsidy Levels Has Drawbacks 49-50 (1994).

${ }^{207}$ A recent study by the General Accounting Office examined the effect that computing FMRs on a county-wide basis would have in increasing access of lowincome households to suburban jurisdictions in metropolitan Washington, D.C. The authors of the study estimate that under current metropolitan FMR calculation methods, 73\% of the housing in Washington, D.C. is available to Section 8 recipients, whereas in suburban Montgomery and Fairfax counties the proportions are only $35 \%$ and $23 \%$, respectively. See id. at 32 . County-wide calculation of FMRs would, however, drive up the cost of the Section 8 program by increasing the level of 
To achieve Section 8's full potential in facilitating deconcentration of the inner-city poor, experience has shown that providing information to tenants about communities outside their immediate neighborhoods and assistance in locating available apartments can be useful. One example of such a counselling program is the Gautreaux Assisted Housing Program in Chicago. As a result of a court decision that found HUD and the Chicago Housing Authority liable for the racial segregation of Chicago public housing, ${ }^{208}$ over 6000 prospective public housing tenants have been given Section 8 certificates to rent homes in the suburbs. Under the Gautreaux program, a nonprofit organization recruits landlords and provides information and advice to tenants about locations with which they might not otherwise be familiar. ${ }^{209}$ Surveys of households participating in the program have found high levels of satisfaction among tenants with both their housing and neighborhoods. ${ }^{210}$

Finally, some evidence suggests that one of the reasons the Section 8 program has not achieved substantial deconcentration is that many landlords are reluctant to offer apartments to recipients of the subsidies. ${ }^{211}$ Among the reasons for this reticence are the rights that must be accorded to Section 8 tenants. When faced with problem tenants, private landlords frequently choose not to commence costly and time-consuming eviction proceedings prior to the end of their lease terms, but instead refuse to renew the tenants' leases. ${ }^{212}$ Section 8 tenants, however, have the right to renew

subsidies and administrative costs. See id. at 37-46.

${ }^{208}$ See Gautreaux v. Chicago Hous. Auth., 503 F.2d 930, 939 (7th Cir. 1974) (concluding that, in order to remedy the effects of public housing discrimination, HUD and CHA would have to include suburban areas surrounding Chicago in a comprehensive desegregation plan), aff'd sub nom., Hills v. Gautreaux, 425 U.S. 284 (1976).

${ }^{209}$ See Mary Davis, The Gautreaux Assisted Housing Program, in HousING MARKETS AND RESIDENTIAL MOBILITY 243, 245-47 (G. Thomas Kingsley \& Margery A. Turner eds., 1993) (describing how the Gautreaux program helps eligible families locate housing).

${ }^{210}$ See James E. Rosenbaum \& Susan J. Popkin, Economic and Social Impacts of Housing Integration 21 (1990) (unpublished report to the Charles Stewart Mott Foundation, on file with authors) (finding that suburban movers are more satisfied with neighborhood safety, police protection, and schools than households that remained in city).

${ }^{21}$ See, e.g., MERYL FINKEL, ABT ASSOCIATES, INC., FINAL REPORT ON RECOMMENDATIONS ON WAYS TO MAKE THE SECTION 8 PROGRAM MORE ACCEPTABle IN THE Private Rental Market 10-12 (1994); Thomas R. Shuler, Testimony Before the House Comm. on Banking, Housing and Community Development on Housing Assistance Payment Programs (Nov. 3, 1993) (on file with authors).

${ }^{212}$ See FiNKEL, supra note 211, at 11. 
their leases indefinitely unless they commit "serious or repeated violation of the terms and conditions of the lease" or the landlord can show "other good cause." ${ }^{213}$ In addition, once a landlord accepts one tenant with a Section 8 voucher or certificate, federal law prohibits him or her from discriminating against future tenants on the ground that they receive federal assistance. ${ }^{214}$ These rules, designed to assist poor households in obtaining and holding onto housing, may have the perverse effect of harming low-income families by scaring away landlords and limiting the supply of housing made available under the program. ${ }^{215}$

\section{Distressed Public Housing}

For many of the inner-city poor, public housing is the problem rather than the solution. Overwhelming concentrations of poor households and half-abandoned buildings provide a hellish environment for residents. ${ }^{216}$ In addition, our analysis in Part II suggests that public housing generates neighborhood effects that blight the community in which it is located. ${ }^{217}$ This is especially true for the nearly vacant, physically deteriorated projects that cannot be

${ }^{213} 42$ U.S.C. § $1437 f(d)(1)(B)(i i)$ (1988). "Other good cause," as further elaborated by HUD regulations, may include disturbing neighbors, criminal activity, poor housekeeping, and the owner's desire to use the unit for personal or family purposes. See 24 C.F.R. § 882.215(c)(2) (1994).

${ }^{214}$ See 42 U.S.C. $\$ 1437 f(t)$.

${ }^{215}$ Before eliminating or modifying these legal protections, however, their costs and benefits should be carefully analyzed. Although Section 8 landlords cannot refuse to renew the leases of subsidized tenants who cause problems, it is unclear how often landlords of unsubsidized tenants can cause their tenants to vacate merely by failing to renew their leases. Under state law, tenants typically may be removed against their will only by bringing an action in court for possession of the premises. Furthermore, even if the protections tend to prevent landlords from offering their apartments to Section 8 recipients, it is unclear what the appropriate legislative response should be. For example, instead of eliminating the nondiscrimination rule for landlords who rent to Section 8 tenants, some commentators have argued that the rule should be extended to all private and public landlords. See Section 8 Housing Assistance Payments Program: Hearing Before the Subcomm. on Housing and Community Development of the House Comm. on Banking, Finance and Urban Affairs, 103d Cong., 1st Sess. 48-49 (1993) (statement of David B. Bryson, Deputy Director, National Housing Law Project).

${ }^{216}$ See, e.g., Alex Kotlowitz, There ARe No Children Here: The STORY OF TWO BOYS GROWING UP IN THE OTHER AMERICA (1991) (describing the lives of two children in Chicago's Henry Horner Homes); NICHOLAS LEMANN, THE PROMISED LAND: THE GREAT BLACK MIGRATION AND HOW IT CHANGED AMERICA 225-31, 295-97 (1991) (describing life in Chicago's Robert Taylor Homes).

${ }^{217}$ See supra part II.A.2. 
demolished by PHAs because of Congress's one-for-one replacement law. ${ }^{218}$ Relaxing the restrictiveness of the replacement rules would not only improve inner-city neighborhoods, ${ }^{219}$ but would also promote deconcentration. If PHAs were able to replace demolished public housing units by providing former tenants with housing vouchers or certificates, not only would neighborhood eyesores and nuisances be removed, but recipients of the housing subsidies would be given the opportunity to locate housing outside of their current neighborhoods.

With respect to existing public housing developments that are not physically distressed and newly constructed developments, Congress and PHAs can learn much from the past. Housing policies that spatially concentrate poor people are bound to fail. Government subsidy programs tied to particular developments can avoid repeating the mistakes of the past by requiring mixed-income tenant populations. ${ }^{220}$ However, achieving economic mix in subsidized housing developments requires legislation. Current federal laws requiring over three-quarters of project-based subsidized units to be rented to the very poor $^{221}$ would need to be amended. Furthermore, rules that currently provide incentives for working families to leave public housing would have to be eliminated through the expansion and liberalization of ceiling rents.

Recent proposals by the Clinton Administration to make public housing more responsive to the market ${ }^{222}$ may also have merit. Under these plans, PHAs would no longer receive federal operating

${ }^{218}$ See supra text accompanying notes 117-20.

${ }^{219}$ Professor Roisman's speculation about our view on the one-for-one replacement requirement is incorrect. See Roisman, supra note 62, at 1369-72. Rather than requiring all PHAs to replace demolished public housing developments with newly constructed public housing, we believe that any replacement housing that is statutorily required should be subsidized through demand-oriented assistance.

${ }_{220}$ For example, in Chicago, two public housing towers have been refurbished and renamed Lake Parc Place. The Chicago Housing Authority obtained special legislation from Congress to lease half of the apartments in the development to households earning between $50 \%$ and $80 \%$ of the area's median income. See Cranston-Gonzalez National Affordable Housing Act, Pub. L. No. 101-625, § 522, 104 Stat. 4207, 4211 (1990) (codified at 42 U.S.C. \$ $1437 f$ (Supp. II 1990 \& Supp. V 1993)). New public housing is also being constructed near the infamous Cabrini Green development, which will also be leased to working-class families. For a discussion of Chicago's mixed-income public housing, see Michael H. Schill, Chicago's Mixed Income New Communities Strategy, in AFFORDABLE HOUSING AND URBAN DEVELOPMENT IN THE U.S.: LEARNING FROM FAILURE AND SUCCESS (Willem van Vliet ed., forthcoming 1995).

${ }^{221}$ See Pub. L. No. 101-625, § 511, 104 Stat. at 4194 (1990).

${ }^{222}$ See, e.g., U.S. DEP'T OF HOUS. AND URBAN DEV., HUD REINVENTION: FROM BLUEPRINT TO ACTION 33-47 (1995). 
subsidies. ${ }^{223}$ Instead, all current tenants of public housing would receive housing vouchers or certificates that could be used either for their existing apartments or for housing owned by private landlords. ${ }^{224}$ High-performing PHAs would be able to retain existing tenants, whereas those that are poorly managed or have housing stocks that are substandard in terms of quality or location would likely be forced either to improve their performance or demolish surplus housing. Current proposals are somewhat unclear as to whether PHAs will be able to lease their vacant units to moderate-income, unsubsidized households. ${ }^{225}$ To the extent that PHAs are permitted this flexibility, "vouchering out" public housing can be a useful tool to deconcentrate poverty by enabling very lowincome tenants to move elsewhere and by permitting PHAs to attract more economically diverse tenants. ${ }^{226}$

\section{CONCLUSION}

Over a quarter century since the Kerner Commission warned that America was "moving toward two societies, one black, one white-separate and unequal, ${ }^{n 27}$ the spiral of decline continues for central cities. Large portions of American inner cities are now home to an overwhelmingly poor, racially segregated, physically isolated, and socially marginalized population. Crime, drug abuse, school dropouts, teenage pregnancies, and intergenerational welfare dependency create environments in which opportunities for social mobility have all but disappeared.

In this Article, we have presented evidence to show that federal housing laws and policies have contributed to the isolation and concentration of poor people in inner-city communities. Sometimes intentionally, perhaps more often unintentionally, this spatial bias

${ }^{223}$ See id. at $41-43$.

${ }^{224}$ See id. at 42.

${ }^{225}$ Compare id. at 39 (permitting PHAs to disregard certain income of tenants during the transition period) with id. at 43 (requiring PHAs to follow low-income use rules).

${ }^{226}$ This is not to say that the transitional issues in transforming public housing will not be daunting. In particular, to the extent that significant numbers of tenants leave developments for housing owned by private landlords, downsizing public housing may create difficult administrative and physical challenges for PHAs. Additional resources might be needed to relocate tenants from half-vacant buildings and to demolish the empty structures.

${ }^{227}$ RePORT OF the National. Advisory Commission on Civil Disorders 1 (1968). 
of housing law and policy continues to shape cities today. Importantly, however, it is not too late for the federal government to implement legislation to ameliorate urban problems. The future of America's cities and the people who live in them depend on it. 